\title{
LAS ÚLTIMAS VOLUNTADES DE LOPE GÓMEZ DE MARZOA: UN OME PODEROSO Y MUY EMPARENTADO EN LA CIBDAD DE SANTIAGO
}

\author{
Amparo Rubio Martínez* \\ Instituto Universitario de Historia Simancas (UVA) \\ Miguel García-FernándeZ** \\ Universidad de Santiago de Compostela
}

\begin{abstract}
* Este trabajo se inscribe en el marco del proyecto de investigación: "Linaje, parentela y poder: la pirámide nobiliaria gallega (siglos XIII al XV)" (II) Ref. HAR2013-42985-P, que se lleva a cabo en el Instituto de Estudios Gallegos "Padre Sarmiento", cuyo investigador principal es el Dr. Eduardo Pardo de Guevara y Valdés, y del proyecto "Poder, sociedad y fiscalidad al norte de la Corona de Castilla en el tránsito del medievo a la modernidad" Ref. HAR2014-52469-C3-3-P, dirigido por el Dr. Hilario Casado Alonso (UVA), este último desarrollado en el marco de la red temática de investigación cooperativa Arca Comunis.

** Departamento de Historia. Contratado del Programa de Formación del Profesorado Universitario del Ministerio de Educación, Cultura y Deporte e Investigador en Formación y Perfeccionamiento en el Grupo de Investigación GI-2108 "Historia social de Galicia en la Edad Media". Este trabajo se ha realizado en el marco de los proyectos de investigación "La formación de la monarquía feudal en Hispania. Sociedad y poder en la época de la dinastía Navarra (1000-1135)" (HAR2012-31940), del que es investigador principal el Dr. Ermelindo Portela Silva, y "Voces de mujeres en la Edad Media: realidad y ficción (siglos XII-XIV)" (FFI2014-55628-P), cuya investigadora principal es la Dra. Esther Corral Díaz. Asimismo, se enmarca dentro de la realización de la tesis doctoral La posición de las mujeres en la sociedad medieval. Un análisis de la práctica testamentaria en la Galicia de los siglos XII al XV.
\end{abstract}

Copyright: (C) 2016 CSIC. Este es un artículo de acceso abierto distribuido bajo los términos de una licencia de uso y distribución Creative Commons Attribution (CC-by) España 3.0.

Cómo citar/Citation: Amparo Rubio Martínez y Miguel García-Fernández, "Las últimas voluntades de Lope Gómez de Marzoa: un «ome poderoso y muy emparentado en la cibdad de Santiago»", Cuadernos de Estudios Gallegos, 63, núm. 129 (2016), págs. 243-286, DOI: http:// dx.doi.org/10.3989/ceg.2016.129.07 


\title{
LAS ÚLTIMAS VOLUNTADES DE LOPE GÓMEZ DE MARZOA: UN OME PODERO- SO Y MUY EMPARENTADO EN LA CIBDAD DE SANTIAGO
}

\begin{abstract}
RESUMEN
El objetivo del presente trabajo consiste en dar a conocer las últimas voluntades del regidor y notario compostelano Lope Gómez de Marzoa. Además de analizar sus disposiciones testamentarias, se estudiarán brevemente algunos de los aspectos menos conocidos de su biografía, tratando de clarificar especialmente sus orígenes familiares y su papel como hombre de negocios y miembro de las élites urbanas en la Galicia del siglo XV. Asimismo, se hará referencia a algunos de los pleitos en los que se vieron inmersos tanto él como, sobre todo, sus herederos. Finalmente, se publican los nuevos documentos que permiten reconstruir los últimos momentos y voluntades de Lope Gómez de Marzoa.

Palabras Clave: testamentos, élites urbanas, negocios, Santiago de Compostela, siglo XV.
\end{abstract}

\section{AS ÚLTIMAS VONTADES DE LOPE GÓMEZ DE MARZOA: UN OME PODEROSO Y MUY EMPARENTADO EN LA CIBDAD DE SANTIAGO}

Resumo

O obxectivo do presente traballo consiste en dar a coñecer as últimas vontades do rexedor e notario compostelán Lope Gómez de Marzoa. Ademais de analizar as súas disposicións testamentarias, estudaranse brevemente algún dos aspectos menos coñecidos da súa biografía, tratando de clarificar especialmente as súas orixes familiares e o seu papel como home de negocios e membro das elites urbanas na Galicia do século XV. Así mesmo, faráse referencia a algúns dos preitos nos que se viron inmersos tanto el como, sobre todo, os seus herdeiros. Finalmente, publícanse os novos documentos que permiten reconstruír os últimos momentos e vontades de Lope Gómez de Marzoa.

Palabras ClaVE: testamentos, elites urbanas, negocios, Santiago de Compostela, século XV.

\section{LAST WILL OF LOPE GÓMEZ DE MARZOA: A WELL-TO-DO AND VERY WELL RE- LATED MAN IN THE CITY OF SANTIAGO}

\begin{abstract}
The aim of this paper is to make known the last wills of Lope Gómez de Marzoa, city councilor and public notary of Santiago de Compostela. Apart from analising his testamentary dispositions, some of the less well-known aspects of his biography will be briefly studied. This will be done specially trying to clarify his family roots and his role as businessman and member of urban elites in Galicia during the 15th century. Besides, this essay will make reference to some of the litigations in which he, and, above all, his heirs were involved. Finally, the article makes public new documents that allow to reconstruct the last moments and wills of Lope Gómez de Marzoa. KeY words: testaments, urban elites, business, Santiago de Compostela, $15^{\text {th }}$ century.
\end{abstract}


Recibido/Received: 30/03/2016

Aceptado/Accepted: 22/06/2016

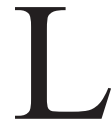

os testamentos y otros documentos vinculados a la práctica testamentaria constituyen una fuente de conocimiento histórico de primer orden debido a la cantidad y heterogeneidad de los datos que aportan sobre aquellos que decidieron otorgar sus últimas voluntades ${ }^{1}$. Más allá de su estudio desde la perspectiva de la historia de la muerte, de clara ascendencia francesa, es la historia social la que permite un mayor aprovechamiento de los testamentos y documentos afines ${ }^{2}$. Interesa saber cómo los testadores encaraban el momento de la muerte, pero, sobre todo, qué nos dicen sobre sí mismos y sobre aquellas mujeres y hombres de su entorno más próximo. Como han señalado Ermelindo Portela y M. ${ }^{a}$ Carmen Pallares, se trata fundamentalmente de hacer una "historia de la vida, de la vida social, desde el punto de vista en que ésta es condicionada, explicada por la idea de la muerte"3. En este sentido, los testamentos permiten combinar al mismo tiempo un estudio "masivo" de los mismos, a partir del cual es posible conocer los comportamientos colectivos, junto con estudios "de caso", que contribuyen al mejor conocimiento de determinadas figuras históricas. De esa forma, se puede aprehender el peso de lo social y de lo individual en el momento de escriturar las últimas voluntades, lo que se hace fundamentalmente tomando como punto de partida un formulario notarial más o menos estereotipado.

¿Qué interés tiene dar a conocer las últimas voluntades de Lope Gómez de Marzoa? En primer lugar, se trata de ofrecer a la comunidad científica un nuevo instrumento con el que enriquecer el corpus testamentario de la Galicia

\footnotetext{
1 Abreviaturas utilizadas: AGS (Archivo General de Simancas), CMH (Contaduría Mayor de Hacienda), EMR (Escribanía Mayor de Rentas), RGS (Registro General del Sello), ARChVa (Archivo de la Real Chancillería de Valladolid), ACS (Archivo de la Catedral de Santiago), AHUS (Archivo Histórico Universitario de Santiago).

2 Algunas reflexiones sobre el tema, aplicadas fundamentalmente al estudio de la nobleza bajomedieval gallega, pero extensibles en gran medida al patriciado urbano, en Pablo S. Otero PiñeYro Maseda y Miguel García-Fernández, "Los testamentos como fuente para la historia social de la nobleza. Un ejemplo metodológico: tres mandas de los Valladares del siglo XV", Cuadernos de Estudios Gallegos, LX, 126 (2013), págs. 125-169.

3 Ermelindo Portela Silva y M. ${ }^{a}$ Carmen Pallares Méndez, "Muerte y sociedad en la Galicia medieval (siglos XII-XIV)", Anuario de Estudios Medievales, 15 (1985), pág. 189.
} 
de finales de la Edad Media. Como punto de partida, esta finalidad heurística justificaría por sí misma un trabajo como este, ya que cada nuevo documento permite ampliar y dar solidez a la base a partir de la cual es posible enriquecer y construir un sólido conocimiento histórico. Además, al margen del análisis aquí realizado, se considera conveniente facilitar el acceso colectivo a la propia fuente ya que ello permitirá su relectura constante por parte de los investigadores, aplicando cada uno un sistema de interrogantes diferente en función de las líneas de trabajo que se desarrollen. Aquí ofreceremos, por tanto, un análisis, pero no el único posible.

Además, en el caso del testamento de Lope Gómez de Marzoa se trata de un documento inédito que interesa de forma particular a los estudiosos de la realidad gallega de finales de la Edad Media por la importancia histórica del testador. Al margen de las polémicas existentes en torno a la verdadera fecha fundacional de la Universidad de Santiago de Compostela ${ }^{4}$, el notario compostelano Lope Gómez de Marzoa aparece como una figura clave en esos difusos orígenes al haber sido el fundador de un colegio para estudiantes pobres en Compostela en el año $1495 \mathrm{y}$, tras el fracaso de dicha institución, uno de los promotores y patronos del Estudio General instituido en 1501. Se trata, pues, de una figura en gran medida excepcional, aunque, paradójicamente, no podemos caracterizar su testamento sino como un documento de últimas voluntades "ordinario", tal vez apurado. Precisamente por ello, constituye un ejemplo representativo de lo que nos encontramos en la mayoría de testamentos pertenecientes al patriciado urbano sin caer en la edición de un instrumento notarial que, de ser excepcional, no podría ser considerado en modo alguno como paradigmático de la realidad del momento. En este caso, podríamos considerar que sí lo es, compartiendo grandes similitudes con otros instrumentos otorgados por sus coetáneos. Precisamente, es a través de la comparación con algunos de esos documentos como podemos tratar de concretar algunos silencios o generalidades que han quedado plasmados en las últimas voluntades de Lope Gómez de Marzoa. Pero, veamos, ¿quién fue Lope Gómez de Marzoa?

\footnotetext{
4 Véase el análisis crítico sobre el tema publicado por Antón Costa Rico, "1526: A fundación da Universidade de Santiago", Cuadernos de Estudios Gallegos, XLVI, 111 (1999), págs. 31- 57. Este autor rechaza la consideración de situar el origen de la Universidad de Santiago de Compostela en los proyectos realizados por Lope Gómez de Marzoa, frente a la opinión de otros investigadores como Xosé Ramón Barreiro que han insistido en la continuidad de estos proyectos hasta la cristalización definitiva de la Universidad compostelana. Véase Xosé Ramón BARREIRo (coord.), Historia da Universidade de Santiago de Compostela. Volumen I. Das orixes ó século XIX, Santiago de Compostela, Universidade de Santiago de Compostela, 1998, págs. 23-97.
} 


\section{Lope Gómez de Marzoa: una SEMBlanZa BIOGRÁFICA}

La figura de Lope Gómez de Marzoa ha despertado el interés de diversos investigadores, sobre todo entre aquellos que han reflexionado sobre los orígenes de la Universidad de Santiago de Compostela o sobre la realidad cultural gallega al final de la Edad Media ${ }^{5}$. Sin embargo, más recientemente, las perspectivas se han ampliado para considerar su destacado papel en diversos negocios y actividades económicas desarrolladas en el Reino de Galicia a lo largo del siglo XV ${ }^{6}$.

Entre estas actividades, quizá la más destacada sea la participación de Lope Gómez de Marzoa en el arrendamiento y recaudación de las rentas reales. Particularmente, en la década de los años treinta y cuarenta del siglo XV, se sitúa al frente de la recaudación de las alcabalas de Pontevedra.

También por estos años, Lope Gómez aparece desempeñando el cargo de notario o escribano mayor en la villa de Pontevedra, un oficio que desempeñará posteriormente en la ciudad de Santiago, concretamente desde mediados de los años cincuenta en adelante ${ }^{7}$. Por otra parte, su actividad como notario aparece continuamente vinculada a diversas operaciones comerciales, en las que se le documenta desde mediados de los años cuarenta. Esto explica que en 1494 encontremos a Lope Gómez de Marzoa ejerciendo su oficio de notario en Purchena, seguramente atraído por alguna operación comercial de gran calado, pues a partir de esta fecha no volvemos a tener rastro de su presencia en dicho lugar ${ }^{8}$.

De las actividades profesionales desempeñadas por Lope Gómez de Marzoa, de la que ha quedado más huella en la documentación es de su participación como recaudador de las alcabalas de ciertos ramos de la actividad económica en Pontevedra (carne, paños, navíos, hierro, cueros y zapatería), una actividad

\footnotetext{
5 José García Oro, Diego de Muros III y la cultura gallega del siglo XV, Vigo, Galaxia, 1976, págs. 83-90; X. R. BARreIro (coord.), Historia da Universidade ..., op. cit., págs. 31-32; Fernando López Alsina, "Marzoa, Melgar, Muros, Fonseca: de la escuela medieval al estudio universitario en Galicia”, Compostellanum, 43 (1998), págs. 799-806.

6 Amparo Rubio Martínez, "Un hombre de negocios a fines del siglo XV: el notario santiagués Lope Gómez de Marzoa", en David Carvajal de la Vega, Imanol Vítores Casado y Javier Añíbarro Rodríguez (eds.), Poder, fisco y mercado en las ciudades de la Península Ibérica (siglos XIV-XVI), Valladolid, Castilla Ediciones - Colección Historia, 2015, págs. 127-142.

7 La documentación consultada menciona a la figura de Lope Gómez de Marzoa desde finales de los años treinta hasta los primeros años del siglo XVI. Ello nos hace pensar que quizá pudiera tratarse de dos personas diferentes, padre e hijo seguramente. De ser así, el Lope Gómez de Marzoa que interviene en la segunda mitad del siglo XV como arrendador de las rentas reales, participando en destacadas operaciones en relación con el comercio marítimo, podría haber heredado el nombre y la actividad profesional de su padre. Sin embargo, no se ha hallado documentación que pueda confirmar esta hipótesis, pudiendo esbozarse otras líneas de trabajo respecto a su genealogía, como se verá más adelante.
}

8 AGS, RGS, Madrid, 8 de octubre de 1494, fol. 267. 
en la que se embarcaría junto a otros personajes de su misma categoría, como el notario Juan Afonso da Pedreira.

Sin embargo, la participación del notario Marzoa en el arrendamiento y recaudación de las rentas reales se intensificaría de manera considerable desde principios de los años ochenta del siglo XV en adelante. A partir de estos años tenemos noticia de su actuación como arrendador de las albaquías, cantidades que el reino de Galicia debía a la Hacienda Regia correspondientes al periodo 1453-77. Mediante un acuerdo con el Contador Mayor de Cuentas, Alonso de Quintanilla, se encargaba al notario Marzoa recaudar las cantidades que el reino de Galicia no había pagado a la Hacienda Regia en concepto de tributos ordinarios y extraordinarios correspondientes al periodo mencionado, además de las que habían percibido de manera ilícita por ciertos poderosos, con excepción de las que habían sido tomadas por el arzobispo de Santiago y el conde de Lemos, así como por los recaudadores de ciertos partidos fiscales y aquellas personas que hubiesen obtenido cartas de finiquito que les eximiese del pago.

Con posterioridad al acuerdo efectuado con Quintanilla en 1484, tenemos noticia de la participación directa de Lope Gómez de Marzoa en la recaudación de las rentas del arzobispado de Santiago con el obispado de Tui de los años 1484-87, que en estos años se encontraban a cargo de Luis de Alcalá, lo que pone de manifiesto su colaboración con reputados financieros y hombres de negocios que tenían arrendadas las rentas de los principales partidos fiscales de la Corona de Castilla.

Dos años después, desde los órganos hacendísticos se encargaba a Lope Gómez de Marzoa recaudar las cantidades que debía a la Hacienda Regia el conde de Camiña, Pedro Álvarez de Sotomayor, así como aquellas que hubiesen sido percibidas por particulares de manera ilícita entre los años 1453-1477.

Posteriormente, entre los años 1488-1491, se le localiza por primera vez como arrendador y recaudador mayor de las rentas ordinarias del arzobispado de Santiago con el obispado de Tui, y diez años después, entre 1498 y 1499, aparece arrendando las rentas de los obispados de Lugo y Mondoñedo. Su interés por el negocio fiscal, así como por los amplios márgenes de beneficio que generaba esta actividad, provocó el choque de intereses con el principal arrendador de las rentas reales del reino de Galicia, Ruy Martínez de Carballido, con quien mantendría pleito en la Chancillería de Valladolid en los últimos años de la centuria. El arrendador Carballido acudía a la Real Audiencia de Valladolid denunciando la sustracción de documentos por parte de su adversario, el notario Marzoa, y señalaba la necesidad de apelar ante el más alto tribunal de justicia ante la imposibilidad de obtener cumplimiento de justicia en primera instancia, por ser como era Lope Gómez ...ome poderoso y muy emparentado en la cibdad de Santiago 
y uno de los cuatro escribanos della de cámara que en la dicha cibdad dis que non pudiera alcançar del cumplimiento de justicia ni le sería fecho...9.

Tras su intervención como arrendador de las rentas del arzobispado de Santiago, en los años 1498 y 1499 conseguía hacerse con las rentas de los obispados de Lugo y Mondoñedo, en colaboración con su factor, Fernando de Madrid ${ }^{10}$, un conocido hombre de negocios con gran experiencia en el mundo financiero, sobradamente acreditada por su continua presencia en los arrendamientos de los principales partidos fiscales de Castilla la Nueva ${ }^{11}$.

La dedicación de Lope Gómez de Marzoa al negocio financiero se constata hasta los últimos años de su vida, teniendo noticia de su actuación como recaudador de las rentas reales del arzobispado de Santiago de los años 1500-1501, que habían sido arrendadas por el pontevedrés Pedro Cruu, una operación en la que participaron conocidos financieros que operaban en otras áreas geográficas de la corona de Castilla como Juan Rodríguez de Pisa, Fernando de Cuenca, Álvaro de Brasy o el propio hermano del arrendador pontevedrés Pedro Cruu, Gómez Cruu.

Directamente relacionada con su dedicación al mundo de las finanzas, se cuenta también su actividad como prestamista en la ciudad de Santiago. Precisamente en mayo de 1496, Juan Fernández Payo da Cana, vecino de Santa María de Conxo, otorgaba una escritura de obligación a favor de Lope Gómez de Marzoa, por el dinero que éste había prestado al bachiller Alonso Caldero, actuando Payo da Cana como fiador o avalista de la operación ${ }^{12}$.

En definitiva, es posible afirmar que el perfil de mercader, financiero, escribano y hombre de negocios que caracteriza a Marzoa no es único en la Galicia del siglo XV, sino que estas mismas características definen a un amplio conjunto de mercaderes y hombres de negocios de la época, que participan al mismo tiempo

\footnotetext{
9 ARChVa, Registro de Ejecutorias, Caja 24, 18, Escribanía de López Julián.

${ }^{10}$ AGS, EMR, leg. 64, fols. 376, 380, 382, 383 y 384, leg. 65, fols. 241, 243 y 245, leg. 66, fols. 244 , $252,253,265$ y 267 , leg. 67, fols. 292, 294, 298 y 299, leg. 69, fol. 215 (1498), leg. 68, fol. 316, leg. 69, fols. 216 y 218 , leg. 71 , fols. 111 y 113, leg. 73, fols. 265,269 y 270 y leg. 93 , fol. 144 (1499).

${ }^{11}$ Pablo Ortego Rico, "Arrendadores mayores y arrendadores menores. La configuración de redes socioeconómicas a través de la gestión de la Hacienda Real a fines del siglo XV: algunos ejemplos", en Ángel Galán Sánchez, Ernesto García Fernández e Imanol Vítores Casado (coords.), En busca de Zaqueo: los recaudadores de impuestos en las épocas medieval y moderna, Madrid, Ministerio de Economía y Hacienda, Instituto de Estudios Fiscales, 2012, págs. 99-116. Este autor documenta la presencia de la compañía formada por Gonzalo Fernández de Madrid y Fernando de Madrid, en el arrendamiento de las rentas de Molina de Aragón en 1483, en clara pugna con el judío Mosé Asayol, que actuaba como testaferro de Alonso de Carrillo. Sobre los negocios del financiero Fernando de Madrid, véase también Máximo Diago Hernando, "Vecinos de Madrid al servicio de la Real Hacienda durante el reinado de los Reyes Católicos: los arrendadores de rentas", Anales del Instituto de Estudios Madrileños, 47 (2007), págs. 367-416.

${ }^{12}$ AHUS, San Martiño, 21, sig. Dig. 12, fol. 462r.
} 
de varias actividades con el objetivo de completar los beneficios generados por su actividad principal. No olvidemos que al fin y al cabo todas estas actividades -la mercadería, el negocio fiscal y el desempeño de una escribanía- estaban estrechamente relacionadas, por cuanto el ejercicio de cualquiera de ellas situaba, a quien la desempeñaba, en una situación privilegiada para desarrollar las otras. Así por ejemplo, el oficio de notario o escribano ofrecía la posibilidad de obviar o no registrar buena parte de la mercancía que determinados mercaderes introducían por los puertos, o en los accesos de las ciudades. A su vez, ofrecía la posibilidad al notario o escribano de turno, de adquirir determinadas mercancías en condiciones especialmente ventajosas, permitiéndole a su vez estimar los beneficios que podían generar las rentas reales, al ser conocedor directo del volumen de mercancías que se introducían en los puertos, y en los mercados locales.

Al margen de las actividades profesionales desempeñadas por Lope Gómez de Marzoa, es importante tener en cuenta algunas otras cuestiones a fin de precisar un poco mejor lo que su figura podía significar en la sociedad compostelana de la época. Aunque no vamos a detallar aquí cada uno de los pormenores en relación con el patrimonio y rentas de este personaje, cuestiones que ya han sido abordadas en un trabajo anterior, sí consideramos conveniente mencionar los juros de heredad que sobre las rentas reales poseía Lope Gómez de Marzoa, pues no todos los miembros de la oligarquía compostelana tenían el privilegio de percibir una parte de las rentas reales, y mucho menos si se trataba de juros de heredad situados en las principales villas y ciudades de realengo del reino. En total, Lope Gómez poseía $35.000 \mathrm{mrs}$. de juro de heredad en las rentas de Betanzos (15.000) y Baiona (20.000). El juro de Baiona lo había adquirido en 1489 mediante compra efectuada al conde de Camiña, Álvaro de Sotomayor, por un precio de $210.000 \mathrm{mrs}$. lo que quizá pueda ponerse en relación con el encargo que unos años antes había recibido de la Corona para recaudar las cantidades que el primer conde de Camiña, Pedro Álvarez de Sotomayor, debía a la Hacienda Regia. Es posible también la venta de este juro de heredad al notario compostelano, respondiera a una estrategia ideada desde la Corona con el firme propósito de desplazar al Conde de Camiña de Baiona, una plaza estratégica que había ocupado durante bastantes años en contra de la voluntad declarada de los monarcas. Además de los 20.000 mrs. de juro en las rentas de Baiona, Lope Gómez de Marzoa era titular de otros 15.000 mrs. en las alcabalas de Betanzos, un juro que había adquirido en abril de 1497, a partir de la renunciación que había efectuado en su favor el veinticuatro de Córdoba, Cristóbal de Mesa, al que los Reyes Católicos se lo habían concedido en octubre de $1487^{13}$.

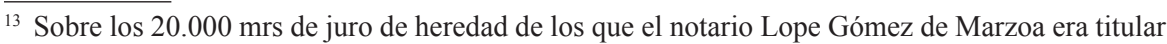
en las alcabalas, diezmos de la mar y alfolíes del reino de Galicia, así como de los 15.000 mrs. de los que era titular en las rentas de Betanzos veáse A. RubIo MARTínez, "Un hombre de negocios...", op. cit., págs. 127-142.
} 
El notario Marzoa disfrutaría de este juro hasta enero de 1502, fecha en la que se subastaban sus bienes muebles y raíces, como consecuencia de las deudas que había contraído de su actividad como arrendador y recaudador mayor de las rentas de los partidos de Lugo y Mondoñedo de los años 1498 y 1499.

Con todo, resulta evidente que Lope Gómez de Marzoa era un personaje de especial relevancia en el reino de Galicia y de confianza para los reyes, al que le habían encomendado la recaudación de las cantidades que adeudaba el reino de Galicia a la Hacienda Regia, facilitándole también la adquisición de juros de heredad en las principales plazas de realengo del reino -Betanzos y Baionaconcretamente.

De todos modos, y como ya se ha señalado, la memoria de Lope Gómez de Marzoa se ha conservado fundamentalmente en relación con la puesta en marcha de dos iniciativas educativas en la Compostela de finales de la Edad Media. En 1495, Marzoa promovió la fundación de un Estudio, para lo cual contó con el apoyo de los monjes benedictinos de San Martín Pinario, quienes le cedieron la casa de San Payo [de Antealtares], cabstras, ortas e ofiçinas, corrales e hedifiçios, eçebto tan solamente el cuerpo de la iglesia, que se reservaba para el culto. Se trataba de fazer e hedificar nesta dicha çibdad un collejo de estudiantes pobres, que Marzoa dotó con diversos bienes raíces y rentas, aunque, finalmente, este colegio parece haber tenido una vida precaria y no muy dilatada en el tiempo ${ }^{14}$.

Ante el fracaso de esa primera empresa cultural de Lope Gómez de Marzoa, a mediados de 1501 se promovió en la ciudad de Santiago la fundación de un estudio general de gramática. En esa ocasión, Marzoa participó en la iniciativa aportando su juro de 20.000 mrs. situados en las rentas de Baiona. Sin embargo, el notario falleció a los pocos meses. Es de destacar que, en este caso, la fundación fue promovida junto a otros importantes personajes del momento, el deán de la catedral compostelana Diego de Muros III y el obispo de Canarias Diego de Muros $\mathrm{II}^{15}$. Ello sirve para comprobar no solo la importancia que tuvieron en la vida y memoria de este hombre de negocios sus fundaciones educativas, sino también la posibilidad de llevarlas a cabo en el seno de una ciudad en la que tenía sólidas bases materiales y profesionales, así como destacadas relaciones con las élites urbanas de las que él mismo formaba parte.

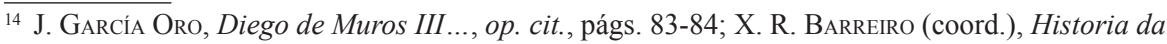
Universidade..., op. cit., págs. 23-35; F. LóPez Alsina, "Marzoa, Melgar, Muros, Fonseca...", op. cit., págs. 799-812; María Xosé Justo Martín, "Lope Gómez de Marzoa na orixe da Universidade, 4 de setembro de 1495", en Gallaecia Fulget (1495-1995). Cinco séculos de historia universitaria, Santiago de Compostela, Universidade de Santiago de Compostela, 1995, pág. 102-107.

${ }^{15}$ J. García Oro, Diego de Muros III..., op. cit., págs. 84-87; X. R. BARreiro (coord.), Historia da Universidade..., op. cit., págs. 37-44.
} 
Es importante destacar que, junto a Lope Gómez de Marzoa, en ocasiones también aparece mencionada su mujer Mayor Fernández. Aunque es cierto que quien está presente y protagoniza la mayoría de los negocios jurídicos que se recogen en los documentos conservados es el notario compostelano, hay que tener en cuenta que a veces actúa con el consentimiento expreso de su mujer -caso de la fundación de $1495^{16}$ - . Ello pone de manifiesto que se trata de actuaciones que afectaban al matrimonio, previsiblemente a los bienes gananciales. Por ello, no resulta baladí mencionar expresamente a la mujer. Una prueba evidente de esta importancia es que, tras la muerte de Lope, Mayor Fernández aparece pleiteando activamente por lo que entendía que era suyo. Lo hacía ya casada en segundas nupcias con un nuevo mercader, Alonso de Salamanca, en una típica estrategia matrimonial de la burguesía bajomedieval. Lo que parece estar claro es que Lope Gómez de Marzoa había encontrado en Mayor Fernández una fiel aliada durante su vida, aunque, tras su muerte, la misma no estaba dispuesta a renunciar a su parte del patrimonio conyugal ${ }^{17}$.

A pesar de lo ya conocido sobre Lope Gómez de Marzoa, sus orígenes familiares resultan prácticamente desconocidos hasta el momento. Sin embargo, ahora podemos arrojar alguna luz sobre los mismos. Como punto de partida hemos tenido en cuenta las informaciones aportadas en el testamento de Inés García, muller que fuy de Alvaro Sanches de Avila, regidor que fuy da çibdade de Santiago $^{18}$. En las últimas voluntades de esta mujer, otorgadas en 1493, la testadora nombra como cumplidores testamentarios a Francisco Gómez e a meu primo Lope Gomez de Marçoa, notario desta dita çibdad. Sin embargo, nos ofrece otro dato de gran interés al nombrar en otra ocasión al dicho Lope Gómez como fillo da dita Costança Gil. Esta información resulta sumamente clarificadora ya que, aunque en el testamento de Marzoa se hace referencia a su madre, no se indica su nombre, lo que dificultaba la identificación de sus orígenes. Por otra parte, esta Constanza Gil era minna tya, según hace constar Inés en su testamento, lo que confirma el parentesco entre la testadora y su cumplidor. Lamentablemente la mención al marido de minna tya Costança Gil, cujas animas Deus aja no resulta

\footnotetext{
${ }_{16}$ Tras dotar su fundación, Lope Gómez de Marzoa dice que "dicha donaçion fago dos ditos bêes sobre ditos ao dito collejo para todo senpre por mi e en nome da dita miña moller e con seu consentimento para que elo oje este dito dia me deu perante o notario de iuso escripto e os quaes ditos bêês suso nonbrados prometo de fazer sanos e çiertos...", haciéndolo además "so obligaçion de mis bienes e dela dicha mi mijer que para ello obligo". X. R. BARreIro (coord.), Historia da Universidade..., op. cit., pág. 27.

${ }^{17}$ Veáse más información al respecto en el tercer epígrafe de este trabajo.

${ }^{18}$ Xosé M. SÁnchez SÁnchez, "Don Álvaro Sánchez de Ávila, tenente de Rocha Forte, o la nobleza gallega bajo-medieval en la transición hacia la Modernidad", Cuadernos de Estudios Gallegos, LVII, 123 (2010), págs. 184-191, doc. 13.
} 
legible, por lo que la identidad del posible padre de Lope Gómez de Marzoa no puede ser desvelada a través de dicho documento.

Sin embargo, otras escrituras pueden ayudarnos a conocer algo más sobre estos orígenes familiares de Lope Gómez de Marzoa. El 2 de mayo de 1464 María Gómez, mujer del correero Juan Sevilla, realizó una venta a favor de Martín Guillén, regidor de la ciudad de Santiago, y de su mujer, Constanza Gil ${ }^{19}$. La venta, por 2.500 mrs., se refería al lugar de Angrois, sito en la feligresía de Santa María de Sar. Esta situación geográfica coincide con una mención a en Angroys outro casal que aparece en la escritura fundacional del colegio para estudiantes pobres que patrocinó en 1495 Lope Gómez de Marzoa ${ }^{20}$. Unos meses más tarde, concretamente el 19 de noviembre de 1464, Constanza Gil, mujer del regidor compostelano Martín Guillén, otorgó en foro a Fernando Calviño, vecino de la feligresía de Santa María de Castrofeito, y a su mujer María Afonso, el casal de Castrofeito por sus vidas, dos voces y veintinueve años a cambio de un renta anual de tres fanegas de trigo, dos capones cebados y la mitad de lo recogido de frutas y castañas ${ }^{21}$. De nuevo, la situación geográfica de la propiedad referida coincide con uno de los elementos patrimoniales con los que Lope Gómez de Marzoa dotó su fundación: en Castrofeyto dous casares $^{22}$. No cabe duda, por tanto, sobre la identidad de la madre de Marzoa, Constanza Gil, pero, además, podemos conocer también el nombre de su marido, Martín Guillén, regidor de Santiago de Compostela. Aunque no consta en ningún documento la filiación directa de Lope Gómez respecto a Martín Guillén sería posible que nos encontrásemos con la figura paterna. De hecho, no resultaría extraño que padre e hijo terminasen desempeñando el mismo cargo, el de regidores de la ciudad de Santiago. Sin duda, estamos ante una familia de la oligarquía compostelana como ya claramente se deducía de los propios datos conocidos sobre la biografía de Lope Gómez de Marzoa o los que sitúan a su prima Inés García como mujer en primeras nupcias del regidor Juan Castellano y, en segundas nupcias, del también regidor y tenente del castillo de A Rocha Forte, Álvaro Sánchez de Ávila.

Como se verá más adelante, en el testamento del propio Lope Gómez de Marzoa aparecen citados sus padres aunque el nombre de su madre nunca es referido y el de su padre solo se entiende como tal si tenemos en cuenta lo expuesto hasta el momento. La primera mención paterna la hace para referir su deseo de ser sepultado donde esta enterrado mi padre en una zona de la Quintana en la que, precisamente, solían enterrarse los burgueses más acomodados. La segunda mención está en relación con el encargo de dos treintanarios por mina anima, y

\footnotetext{
19 ACS, P 003, fols. 175r.-176r.

${ }^{20}$ X. R. BArreiro (coord.), Historia da Universidade..., op. cit., pág. 26.

21 ACS, P 003, fols. 237v.-238v.

${ }^{22}$ X. R. BArreiro (coord.), Historia da Universidade..., op. cit., pág. 26.
} 
de mi padre, y madre, y de aqueles a que sou obligado. Nada, por tanto, permite identificar a los progenitores. Sin embargo, al disponer la entrega de un par de cálices a favor de Santa María de Aciveiro, dice que un abad los había empeñado a mestre Guillen, meu amo, que deus aja y dispone la entrega por descargo das almas do dito mestre Guillén y de mina madre y mya. Sin duda, este Guillén hace referencia al citado Martín Guillén que aparece en la documentación conservada en el Archivo de la Catedral de Santiago. No parece probable que se trate de otro personaje $\mathrm{e}^{23}$. Sin embargo, resulta un tanto extraño que lo nombre como meu amo y no como su padre ${ }^{24}$. Está claro que, al actuar en descargo del alma de este hombre, de la de su madre y de la suya propia, está refiriéndose a una figura familiar, próxima al testador y a esa madre no nombrada en las últimas voluntades de Marzoa pero que se trata, sin lugar a dudas, de Constanza Gil. ¿Era Martín o Mestre Guillén el padre de Lope Gómez de Marzoa o solo el marido de su madre? Resulta complicado posicionarse al respecto al no constar, como ya hemos señalado, un documento en el que se exprese con claridad la filiación paterna y, sin embargo, no ser excepcional que las mujeres contrajesen diversas nupcias a lo largo de sus vidas, como evidencia el propio testamento de Inés García, sobrina de la propia Constanza Gil. En todo caso, el hecho de que Marzoa considera a este hombre como meu amo tal vez responda a que, al margen de que fuese su padre o simplemente su padrastro, fue él quien lo crió. Y, de no ser Martín Guillén el padre, ¿quién pudo haberlo sido? La coincidencia onomástica con Vasco Gómez de Marzoa, un personaje bien documentado en el Libro do Concello de Santiago (1416-1422) resulta, cuando menos, sospechosa ${ }^{25}$. Lamentablemente en este

\footnotetext{
${ }^{23}$ En un documento otorgado hacia 1463, es decir, un año antes de la aparición de Martín Guillén como regidor compostelano y marido de Constanza Gil, aparece citado un Maestre Guillén. Se trata del traspaso realizado por Rodrigo Barbero a Juan Barbero, vecinos de Santiago, del arriendo que tenía con Maestre Guillén por una tienda de barbería sita en la rúa da Moeda Vella. ACS, P 003, fols. $51 \mathrm{r} .-51 \mathrm{v}$.

${ }^{24}$ Entre las acepciones recogidas para este término en la documentación notarial gallega del siglo XV podemos señalar la de "amo, dono e señor respecto ó seu servo", sin olvidar otras como la de "ayo", es decir "persoa encargada do coidado e educación dos nenos". Véanse los resultados de la búsqueda del término "amo" en Ernesto González Seoane (coord.), María Álvarez de la Granja y Ana Isabel Boullón Agrelo, Dicionario de dicionarios do galego medieval, Santiago de Compostela, Universidade de Santiago de Compostela, 2006, edición en línea disponible en http://sli.uvigo.es/ DDGM/ [Consultado el 11/10/2015]. Sin embargo, no hemos documentado referencias en las que se pueda entender con claridad el significado de amo como sinónimo de progenitor.

25 Ángel Rodríguez González, Libro do Concello de Santiago (1416-1422), con la colaboración

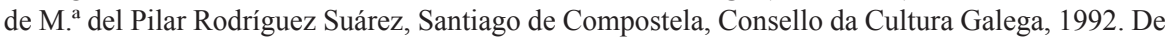
hecho, esta hipótesis ya aparece apuntada por Neira de Mosquera en el siglo XIX, quien habla de "Vasco Gómez de Marzoa, que sería tal vez el padre de Lope Gómez de Marzoa, primitivo fundador del Estudio viejo de Santiago, y notario público de la ciudad". Antonio Neira de Mosquera, "La Hermandad de Santiago. 1418”, Semanario Pintoresco Español, 44 (1851), p. 348.
} 
caso tampoco hemos encontrado referencias a la filiación y, ni siquiera, podemos confirmar el matrimonio con la perfectamente identificada Constanza Gil. Por el momento solo podemos proponer esta posibilidad a modo de hipótesis ${ }^{26}$. Sin embargo, el hecho de que se trate de un cambiador y mercader compostelano que actúa reiteradamente como testigo en las actas del Concejo compostelano en una cronología perfectamente compatible con la que se podría asignar al progenitor de su supuesto hijo podría apoyar dicha hipótesis. Sin duda, estaba en condiciones de ser enterrado junto a la Puerta del Perdón donde sabemos, con total seguridad, que había sido sepultado el padre de Lope Gómez de Marzoa, según indica este último en su testamento. Además, esta filiación explicaría el nombramiento de Martín o Mestre Guillén como amo de Lope Gómez. Por tanto, hemos de dejar abierta esta hipótesis sobre un primer matrimonio de Constanza Gil con Vasco Gómez de Marzoa, fruto del cual nacería Lope Gómez de Marzoa, aunque posteriormente, y como ya consta en la documentación consultada, habría contraído nuevas nupcias con ese otro personaje que aparecen ya claramente citado en el testamento de Lope Gómez como Mestre Guillén ${ }^{27}$.

A pesar de todas estas dudas sobre la filiación de Lope Gómez de Marzoa, podemos enriquecer su genealogía con la referencia a una hermana llamada Inés. Así consta en un instrumento otorgado en 1587, el cual refiere la existencia de un sobrino del notario y mercader compostelano, en cuanto hijo de Ynes Gomez de Marçoa [quien] era hermana legitima de Marzoa, del cual se recuerda que mandó a la Universidad nobe mil maravedies biexos en la vilal de Bayona, junto con las casas del estudio biexo adonde se enseñaba gramatica sitas en la Rua Nueva con mas el pan y trigo de renta ${ }^{28}$. Es de destacar que en dicho documento se habla de Marzoa y Diego de Muros como los primeros fundadores deste colegio, dando por hecho la continuidad existente entre aquellas primeras fundaciones educativas y la cristalización de la Universidad de Santiago.

Lo que está claro es que todo lo conocido sobre los orígenes familiares y sociales de Lope Gómez de Marzoa confirma que fue un notario y hombre de negocios poderoso y muy emparentado en la ciudad de Santiago ${ }^{29}$.

\footnotetext{
${ }^{26}$ En 1430, el cambiador Vasco Gómez de Marzoa adquiría de Gómez Periye, mayordomo de la ciudad de Santiago de Compostela, cierta parte del lugar de Zaramacedo. La noticia en ARCHVa, Pergaminos, Carpeta 166, 7.

${ }^{27}$ En el Libro do Concello de Santiago y muchas veces en las mismas escrituras en las que figura Vasco Gómez de Marzoa aparecen diversas menciones a hombres como Álvaro Gil o Gil Peres, cambiadores y procuradores del Concejo que, siguiendo la lógica de la antroponimia medieval, podrían ser perfectamente parientes de Constanza Gil, lo que, por tanto, dejaría entrever con claridad los estrechos vínculos de amistad y parentesco que existían entre los miembros de la oligarquía compostelana a la que pertenecerían, sin duda alguna, los padres de Lope Gómez de Marzoa.

${ }^{28}$ AHUS, S. H. 156, Exp. 7.

${ }^{29}$ Así aparece nombrado en ARChVa, Registro de Ejecutorias, Caja 24, 18, Escribanía de López Julián.
} 


\section{LAS ÚLTIMAS VOLUNTADES Y LA MUERTE DE UN NOTARIO COMPOSTELANO}

Conocidos a grandes rasgos los avatares vitales de Lope Gómez de Marzoa, vamos a detenernos ahora en analizar sus últimos momentos $\mathrm{y}$, sobre todo, sus mandas testamentarias.

Como resulta habitual, el testamento de Lope Gómez de Marzoa apenas nos aporta datos sobre el momento concreto en que fue otorgado y, obviamente, no nos permite conocer el momento exacto del deceso del testador ni los acontecimientos que siguieron a este hecho. Al fin y al cabo, el testamento es una fotografía fija y, ante todo, una expresión de deseos para un futuro que se prevé cercano la mayor parte de las veces. De todos modos, el testador sí declara que espera que su capellán me tenga por la mano en ese tránsito hacia el Más Allá ${ }^{30}$, una imagen muy acorde con la idea de buena muerte que se divulgaba a través del Ars moriendi. Se desea una muerte tranquila, en el lecho, rodeado de los suyos y en compañía de algún religioso, como ese capellán, que le reconfortaría espiritualmente. En el caso de Lope Gómez sabemos que estaba doliente y muy posiblemente tumbado o recostado en cama. La enfermedad es el motivo fundamental que le lleva a ordenar sus últimas voluntades pues, al fin y al cabo, se trataba de un momento propicio para tomar consciencia de la certeza de la muerte porque tengo de pasar. Más allá de esta reconstrucción del momento a partir de los indicios que nos aporta el testamento, la conservación de otros documentos nos permite mirar por la ventana del pasado y tratar de relatar con mayor precisión esos últimos momentos del notario compostelano.

El 22 de octubre de 1501 una serie de testigos comenzaron a prestar declaración sobre la manda de Lope Gómez de Marzoa, que Dios perdone ${ }^{31}$. Se trata de un proceso que se extendió al menos hasta el 1 de noviembre de 1501, gracias al cual tenemos la oportunidad de conocer el testimonio de seis personas que relatan las circunstancias en las que Marzoa dictó sus últimas voluntades. De hecho, aunque no conservamos la fecha exacta en la que el notario y vecino compostelano otorgó su testamento, este documento marca el término ante quem, pues en ese momento el testador ya había fallecido ${ }^{32}$.

\footnotetext{
${ }^{30}$ De ahí que le deje 300 pares de blancas, también "por diezmos fioyados". ARChVa, Pleitos Civiles, Alonso Rodríguez (F), C. 657, 1. El documento se edita en su integridad en el apéndice documental (doc. 1).

${ }^{31}$ AHUS, Protocolos, S-3, fols. 98r-103v. Véanse las declaraciones en el apéndice documental (doc. 2).

${ }^{32}$ Esta información resulta contradictoria respecto a aquellas otras que advirtieron de la necesidad de situar el fallecimiento de Lope Gómez de Marzoa no antes de diciembre de 1501: "descoñecemo-la data da súa morte, pero López Ferreiro, sen especificar en que se baseaba, escribiu que morrera en setembro de 1501. A autoridade deste mestre provocou a reiteración do erro ata hoxe (...). As investigacións de María Xosé Justo (...) demostran -e así o puidemos constatar directamente na
} 
El sastre Lope de Queizán es el primero en declarar. Estando en casa del testador

la noche quel fallesçio que fue llamado para ser testigo del testamento que fasya el dicho Lope Gomes y que le oyera desir por su boca al dicho Lope Gomes que él dava por su testamento y manda la manda que tenía en sus manos Antonio Rodrigues, sochantre, $y$ Jacome de Figueras, notario de Santiago, y que aquella hera su testamento y su ultyma y postrimera voluntad.

Sabemos, por tanto, que inmediatamente antes de morir, Lope Gómez otorgó un documento que, revocando cualquier otro que hubiese sido otorgado con anterioridad, constituía su última voluntad. Se trata de un testamento cerrado que es entregado estando presente el sochantre Antonio Rodríguez ${ }^{33}$, quien, como veremos, aparece dando fe en el documento que editamos en el apéndice (doc. 1). Por ello, y atendiendo a las similitudes entre el contenido del testamento aquí estudiado y lo declarado por los testigos, dicho documento parece haber sido, si no con total seguridad, sí con muchas probabilidades, el otorgado esa última noche de la vida de Lope Gómez de Marzoa ${ }^{34}$. El testador, según afirma el testigo,

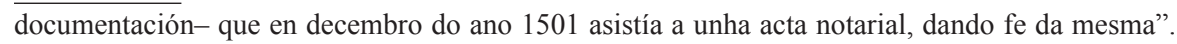
X. R. BARreiro (coord.), Historia da Universidade ..., op. cit., pág. 31. Efectivamente, así lo afirma la propia María Xosé Justo Martín en su trabajo "Lope Gómez de Marzoa na orixe da Universidade...", op. cit., pág. 104. Sin duda, la data y, sobre todo, la presencia de Lope Gómez de Marzoa en ese documento del 31 de diciembre de 1501 entre la ciudad y el monasterio de San Martín Pinario resultan problemáticas a tenor de los documentos que publicamos ahora. Por el contrario, los datos referidos por Antonio López Ferreiro, a pesar de carecer de una referencia documental expresa, coinciden con los disponibles en nuestra documentación, pues en octubre de 1501 se refiere que los herederos y cumplidores de Lope Gómez de Marzoa ya habían realizado una serie de actuaciones respecto a los bienes del difunto -lo que estaría en concordancia con su fallecimiento a lo largo del mes de septiembre-. Además concreta el nombre de sus dos herederos y cumplidores, aunque, frente a las informaciones conservadas en el documento de sus últimas voluntades, López Ferreiro habla de la entrega al cabildo compostelano del coto de Berredo, en el obispado de Ourense, de lo que no queda constancia en su testamento -al menos en el que ahora se da a conocer-, aunque sí de los 5.000 mrs. pares de blancas otorgados a San Francisco. Antonio López Ferreiro, Galicia en el último tercio del siglo XV. Tomo II, A Coruña, Andrés Martínez Editor, 1897, pág. 274.

${ }^{33}$ De él dice el testigo que era rector y clérigo parrochial del dicho Lopo Gomes y, cuando ofrece su testimonio, es presentado como cura, rector y clérigo parrochial de la capilla de Sant Juan que es dentro de la santa yglesia de Santiago y del dicho Lope Gomes por que hera su feligres.

${ }^{34}$ Otro indicio es que Mayor Fernández, la viuda de Lope Gómez de Marzoa, declara el 26 de octubre de 1501 que la noche que fallesció el dicho Lopo Gomes, su marido, llamaron a ciertas personas que fueron el sochantre de Santiago y a Ares Peres de Baruta y a otras personas para que fuesen testigos. Precisamente, estos dos hombres son los que figuran al final de las últimas voluntades que se dan a conocer en el presente trabajo. De todos modos, otros historiadores hablan de un testamento 
estaba en su seso, aunque estaba con grand ardor. Precisamente, en el testamento se señala su condición de doliente. Aún así, al primer testigo en declarar nada le hacía presagiar que el testador estaba viviendo sus últimas horas. De hecho, dice que le viera desir las dichas palabras con muy buen tiento y le viera comer un caldo y que dixera dadme más que buen caldo es, por lo que el sastre pensó que non muriera de aquella dolencia y que yéndose este testigo para su casa le preguntara su muger que tal quedaba el dicho Lopo Gomes y que él respondyera quel non avía de morir de aquella dolençia.

El testimonio del herrero Juan de Betanzos, vecino de Santiago, es prácticamente idéntico al anterior. Nos dice, eso sí, que la que le había dado el caldo era la señora su muger del dicho Lopo Gomes, lo que pone de manifiesto el papel cuidador de Mayor Fernández para con su marido enfermo. También lo ratifica el sochantre de Santiago, Antonio Rodríguez, capellán del propio testador, quien le pidió que firmase la manda que otorgaba por quanto él no la podía fyrmar. Coindice en este relato otro de los testigos llamados para asistir al otorgamiento de las últimas voluntades de Marzoa, Gonzalo de Melide, y un vecino y zapatero de Santiago llamado Martín que prestó declaración el 1 de noviembre.

Pero centrémonos en el contenido del testamento de Lope Gómez de Marzoa. El documento que recoge sus últimas voluntades respeta la estructura típica de este tipo de escrituras. El testador, al fin y al cabo, estaría muy familiarizado con el formulario testamentario debido a su oficio de notario. Aparecen, por tanto, diversas fórmulas que, aunque pueden no ser reflejo exacto de los sentimientos particulares del propio otorgante, evidencian la reiteración de una práctica social continuada que, por tanto, podría acercarnos, al menos, al imaginario colectivo. Ello nos permite tomar en consideración tanto las partes formulares como las de libre disposición pues, de un modo u otro, son evidencia de la realidad histórica del momento.

El documento comienza con la invocación a la divinidad. En este caso, y como resulta cada vez más habitual en los testamentos bajomedievales, se invoca el nombre de Dios, padre y fillo y esperitu Santo, tres personas y un solo verdadero criador y fazedor de todas las cosas. Frente al simple in Dei nomine que encabeza un gran número de escrituras medievales, la aparición de la Trinidad está cada vez más presente en los documentos de últimas voluntades de la Baja Edad Media, en los que se buscaba ordenar lo material, pero también y, muy especialmente, lo

otorgado el 5 de noviembre de 1496, vid. J. García Oro, Diego de Muros III..., op. cit., pág. 94 o, siguiendo al anterior, F. López Alsina, "Marzoa, Melgar, Muros, Fonseca...", op. cit., pág. 805. Sin embargo, parece no ser sino una manda anterior al testamento aquí editado ya que, como venimos señalando, este último parece tener numerosas coincidencias, y, por tanto, corresponderse, con el que habría sido otorgado esa noche que el fallesçió. 
espiritual. Por ello, también suelen aparecer expresiones que certifican la profesión de fe del testador, en este caso con un escueto yo creo y adoro. Se busca así la gracia divina en un momento en el que se quiere ordenar todo lo concerniente al alma, al cuerpo y al patrimonio a su servicio y probeyto da mina alma.

Lope Gómez de Marzoa es presentado como vezino y notario desta çibdad de Santiago. Es habitual que los testamentos masculinos recojan este tipo de caracterizaciones de vecindad y profesión, mientras en los femeninos predomina la expresión del vínculo conyugal, aunque dicha solución no es la única posible y también es habitual que haya referencias a su filiación o que se combinen varios de estos sistemas de presentación.

Siguiendo con la estructura típica de los testamentos, se hace constatar que, a pesar de estar doliente, de la ynfermedad que a nuestro señor Dios aproubo de me dar, el testador está en perfectas condiciones mentales, con todo my seso y entendimiento, como para ser consciente de lo que dispone en sus últimas voluntades. De esa forma se encara una muerte que se acepta como algo natural pero a la que no por ello se deja de temer.

Uno de los momentos clave del testamento es el de la encomendación del alma y la elección de los abogados celestiales a los que se pide su mediación a la hora del juicio, bien el particular, bien el Juicio Final. En el caso estudiado se recurre prácticamente a la fórmula más simple: poner el alma en manos de Jesucristo, que la compró y redimió por su santa y preçiosa sangre, y nombrar a la Virgen María como señora y abogada con toda la corte celestial. La intercesión de María a favor de los testadores se convierte en una realidad omnipresente en la práctica totalidad de los testamentos bajomedievales, constituyendo la prueba definitiva de la implantación de la devoción mariana en los últimos siglos de la Edad Media. Se entiende que es la mejor mediadora posible ante el Hijo con el objetivo de que este no mire a mis grandes maldades y culpas y pecados, mas usando de su clemençia y piedad me queyra perdoar ${ }^{35}$. La Virgen y Jesucristo, centro de las devociones bajomedievales, se presentan como figuras compasivas en el marco de una religiosidad mucho más humanizada que la que se podía percibir en otros momentos de la Edad Media y que está acorde con el éxito de la religiosidad mendicante. Sin embargo, ningún indicio realmente nos habla de las devociones personales de Lope Gómez de Marzoa si es que realmente las tenía. Frente a otros testamentos en los que se especifican otros abogados concretos -especialmente reiterado es el caso de San Miguel, aunque también hay menciones en las mandas gallegas a San Martín o, por supuesto, al apóstol Santiago-, en esta ocasión ni

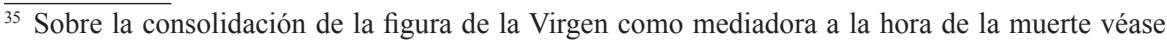
Marina WARNER, Tú sola entre las mujeres. El mito y el culto de la Virgen María, Madrid, Taurus, 1991, págs. 407-427.
} 
siquiera aparecen alusiones generales a los arcángeles, los santos e santas, los bienaventurados o cualquiera otro colectivo de los que habitarían la corte celestial o el parayso de los que se nos hablan en otros documentos de últimas voluntades. Tal vez esta simplicidad se deba a que el testamento se hacía un tanto apurado y con el objetivo de disponer de una hacienda que, al no ir destinada a un descendiente del testador - pues el mismo no tenía hijos-, era necesario ordenar con mayor urgencia que en otros casos, evitando los posibles problemas que podrían derivar de una muerte ab intestato.

El destino del cuerpo también es otra de las preocupaciones constantes entre los testadores. En este caso se opta por la Quintana de Palaçios -o Paaços, como es más habitualmente referida en las mandas de sus coetáneos redactadas en gallego-. En el caso compostelano, el gran lugar de enterramiento al margen de las iglesias, los monasterios y, por supuesto, la catedral -destinados fundamentalmente a las élites- era la Quintana. De hecho, la parte inferior de la actual plaza de la Quintana se destinó a espacio funerario hasta el siglo XVIII y dicha función dio lugar a su denominación como "Quintana dos mortos". Sin embargo, en el testamento de Lope Gómez se concreta que se está hablando de la Quintana de Paaços, espacio que, según Suárez Otero, habría que relacionar con aquel en el que se había proyectado la realización de la cabecera gótica de la catedral compostelana, pero que finalmente terminó por dar lugar a una zona con un conjunto de capillas funerarias en las que asentaron sus sepulturas los burgueses compostelanos, muy especialmente los sectores más acomodados ${ }^{36}$. Unas décadas antes, precisamente, había dispuesto su enterramiento en esa zona Constanza García, mujer del regidor compostelano Alfonso Rodeiro: mando enterrar o meu corpo enna Quintaan de Paaços enno moymento que está a çerqa do dito meu marido ${ }^{37}$. Lope Gómez de Marzoa concreta un poco más el lugar y también junto a quién deseaba que reposasen sus restos mortales: a la Puerta del Perdón en la sepultura donde está enterrado mi padre.

\footnotetext{
${ }^{36}$ José SuÁrez Otero, "A Quintana de Paaços. Arquitectura, urbanismo y conflicto social en la Compostela bajomedieval”, Quintana, 1 (2002), págs. 285-300.

37 Anselmo López Carreira, "Un rexidor de Santiago do século XV", Brigantium, 6 (1989-1999), pág. 266, doc. 7. En su momento, el editor de dicho documento consideró que esa referencia a "paaços" podía estar relacionada con un "pazo" o palacio concreto -"tal vez o de Arenteiro, no Ribeiro"-. A. López Carreira, "Un rexidor...", op. cit., pág. 254. Sin embargo, no cabe duda de que se refiere realmente a una zona concreta de la Quintana compostelana en la que, como vemos, el patriciado de la ciudad ordenaba sus enterramientos con signos de distinción social, de ahí que Constanza García refiera el moymento que su marido ya había mandado realizar a pesar de que en ese momento todavía estaba vivo y solo testaría años más tarde, concretamente en 1474. A. LóPEZ CARREIRA, "Un rexidor...", op. cit., págs. 268-269, doc. 9.
} 
Aunque no se detallan disposiciones especiales referidas al funeral más allá de pedir que la çera y mis honrras y lutos se fagan como mis conplideros vyeren y acordaren que cumple de se faser, sí se manda que desde el día de su enterramiento y durante los siete días siguientes se hagan misas y pitanzas, lo que da buena muestra de la importancia concedida a las exequias y de la proyección e importancia social que tenía la muerte de aquellos que formaban parte de las élites dirigentes en el seno de la sociedad urbana bajomedieval, sobre todo para el sector eclesiástico, para colectivos como el de los pobres o, incluso, para las cofradías $^{38}$. Estos grupos participaban activamente en el acompañamiento del difunto hasta su última morada y podían llegar a convertirse para este en importantes mediadores en el camino de salvación y consecución de méritos para el Más Allá.

Los pobres, por ejemplo, permitían a los testadores mostrar su misericordia y generosidad con los más débiles. De hecho, la práctica de la limosna es habitual en los documentos de últimas voluntades, bien a través de la entrega de determinadas cantidades o bienes a favor de estos pobres o, sobre todo, mediante la entrega de legados píos a instituciones como hospitales y alberguerías, que ayudaban a este mismo colectivo junto a los enfermos y peregrinos. Aunque se ha hablado de un empeoramiento de la consideración de los pobres en el imaginario colectivo de la sociedad de finales de la Edad Media, no por ello desapareció la práctica de la caridad ${ }^{39}$. Así, en el ejercicio de la misma, el papel de los laicos resultaba destacado, aunque se plasmase mediante la reiteración de pequeñas mandas testamentarias. En el caso que nos ocupa, se dispone que den de comer $y$ de veber a todos los pobres que ovyeren a buscar pan, vyno, carne y pescado como por el dia. De todos modos, a ello habría que sumar las mandas a favor de las instituciones hospitalarias de Santiago ya que, directamente o indirectamente, también revertían a favor de estos sectores más débiles de la sociedad de los que venimos hablando. Así, dejó para el Hospital de Santiago dos libras de azeyte y que den más para ho dito espytal en roupa de cama en que duerman los pobres del, mill pares de blancas. Lope Gómez de Marzoa tampoco se olvidó de otro colectivo muy presente en la sociedad medieval: el de los leprosos. Se trata de un grupo que se mueve entre la enfermedad, la pobreza y la exclusión, y para el que se creó una red de instituciones asistenciales propias, asentadas

\footnotetext{
$\overline{38}$ Ha de tenerse en cuenta que no nos encontramos con un miembro de la nobleza, cuyas exequias podían llegar a convertirse en ocasiones en un auténtico espectáculo. Véase Rocío SÁnchez AmEIJEIRAS, "Un espectáculo urbano en la Castilla medieval: las honras fúnebres del caballero", Semata, 6 (1994), págs. 141-157.

${ }^{39}$ Michel Mollat, Pobres, humildes y miserables en la Edad Media. Estudio social, México, Fondo de Cultura Económica, 1978, y, especialmente para el contexto de la caridad en el tiempo que le tocó vivir a Lope Gómez de Marzoa, págs. 233-237.
} 
habitualmente a las afueras de las ciudades: las leproserías o malaterías ${ }^{40}$. En este caso, se citan las dos malaterías compostelanas: mando a las malaterías de San Lázaro y Santa Marta de a par da dita çibdaad cada una quinientos pares de blancas. Frente a otros casos en que hombres y mujeres compartían la misma institución ${ }^{41}$, en la ciudad de Santiago San Lázaro era destinada a los hombres y Santa Marta a las mujeres ${ }^{42}$.

Por otra parte, los clérigos eran llamados a tener un papel capital no solo en el funeral sino también a la hora de mediar por la salvación del alma del testador después de su óbito. La creencia en un doble Juicio, el particular y el Juicio Final, $y$, la ya plenamente consolidada idea del Purgatorio favorecieron el incremento de legados píos a favor de instituciones religiosas y, en estrecha relación con ello, la fundación de numerosas misas y aniversarios. De ese modo, se trataba de obtener notables beneficios espirituales. Lope Gómez de Marzoa no fue una excepción, a pesar de que, frente a otros testamentos, sobre todo los nobiliarios, no se trataba de cantidades de misas desbordantes.

De partida pide que ho dia de mi enterramiento fasta los syete días le digan diariamente diez misas cantadas y rezadas quantos clérigos se podieren aver para las desir. Se procura dar solemnidad al momento no solo con la cantidad y diversidad de las misas establecidas, sino con esa aspiración por reunir al mayor número posible de clérigos. Además, dispone que los syete días y corenta días y cada año y día me fagan y digan las misas como el día de mi enterramyento, es decir, no se trata de una simple conmemoración del difunto, sino de una recordación especial, dando continuidad a la solemnidad de las exequias.

La fundación de misas y la petición de ser incluido en las oraciones de los religiosos compostelanos se amplían al ir refiriendo los legados píos concedidos a las diversas instituciones que se asentaban en la ciudad y su entorno. Se trata fundamentalmente de cantidades en metálico, así como de la entrega de aceite, uno de los gastos constantes en las iglesias. Lope Gómez de Marzoa entrega de forma general a todas las capyllas de la iglesia y çibdad de Santiago y a todos

\footnotetext{
${ }^{40}$ A falta de estudios específicos sobre el caso gallego, resulta de gran interés conocer otras realidades del Occidente medieval que se intuyen similares. Véase a modo de ejemplo Carole RAwCLIFfE, Leprosy in medieval England, Woodbridge, Boydell \& Brewer, 2006.

${ }^{41}$ Así se observa en la documentación de Santa María do Camiño, malatería pontevedresa, en la que se hace mención a los lazarados e lazaradas da malateria da dita hermida. Vid. María Ángela Comesaña Martínez, O tombo do Hospital e Ermida de santa María do Camiño de Pontevedra, Pontevedra, Museo de Pontevedra, 1995, pág. 145, doc. 45.

${ }^{42}$ Así consta en una escritura de aforamiento de 1426 en la que se habla de las lazaradas de santa Marta. Vid. José María Fernández Sánchez y Francisco Freire Barreiro, Guía de Santiago y sus alrededores, Santiago de Compostela, Imprenta del Seminario Conciliar, 1885 (ed. facsímil Valladolid, Maxtor, 2008), pág. 394.
} 
los mosterios, asy da dita çibdad como los de aredor della a cada uno dos libras de azeyte, añadiendo para los monasterios a cada un çien pares de blancas, a cada uno por que rueguen a Dios por mi, y sin olvidar la entrega de una aroa de azeyte para el fuego del altar del señor Santyago.

El testador también se detiene en especificar aquellas instituciones concretas que, más allá de los ya referidos hospitales y malaterías, recibirían determinados legados a cambio, como no, de obtener sus favores espirituales. Al cabildo de Santiago le otorga $4.000 \mathrm{mrs}$. de pares de blancas para que, en el día de su enterramiento, a los siete días, a los cuarenta y al año y día, dijesen por él una misa cantada y que fuesen a su sepultura con seu responso y que me fagan tanger as canpanas da dita iglesia en cada un dos ditos días; a San Francisco entrega 5.000 pares de blancas para la obra y que me digan dos trintanarios por mina anima $y$ de mi padre y madre y de aqueles a que sou obligado; a Santo Domingo 5.000 mrs. de pares de blancas para la obra del monesterio (...) y que me digan otros dos trintanarios; y para la obra de San Xoán de Calo entrega, finalmente, 1.000 pares de blancas.

Como es habitual en la época y, sobre todo, entre los sectores urbanos, se observa la importancia que tuvieron los mendicantes a la hora de convertirse en los principales beneficiarios de los legados testamentarios y mediadores ante la muerte. Su ya no tan nueva religiosidad estaba plenamente consolidada al final de la Edad Media. Sin embargo, ello no implica que, sobre todo un miembro de la burguesía, olvidase hacer mención a la principal institución de la ciudad, la Catedral. Lo entregado se destina fundamentalmente para la celebración de ciclos de misas, caso de los dos treintanarios citados, aunque no solo por el alma del testador. Es habitual la referencia a la fundación de misas por aquellos por los que uno se siente obligado tanto en los testamentos como en las donaciones pro anima o la fundación de aniversarios. También lo es la referencia a los progenitores, aunque nuevamente se nos escapa conocer la identidad de los mismos al tratarse de una mención general.

Sorprende en cierta forma que una institución compostelana tan poderosa como San Martín Pinario no figure en el testamento de Marzoa. Sin embargo, esta ausencia podría explicarse en cierta medida por la experiencia personal de nuestro testador con dicha institución. Sabemos que en 1495 Lope Gómez de Marzoa contaba con el favor del abad fray Juan de Melgar y de los restantes miembros de la comunidad. Al fin y al cabo, le cedieron el monasterio de San Paio de Antealtares para edificar su colegio de estudiantes pobres. Sin embargo, las cosas cambiaron posteriormente y las relaciones con aquel al que llamaban honrrado Lope Gomes de Marçoa se enfriaron y es muy posible que se rompiesen definitivamente. Sin duda, en todo ello tendría mucho que ver la decisión del Capítulo de San Martín Pinario de anular su concesión del edificio de San Paio de 
Antealtares para asentar allí a una comunidad de benedictinas sin otorgar ningún tipo de compensación a favor de Marzoa, quien también se vio privado el 18 de julio de 1499 de las rentas del monasterio de Camanzo e el coto de Fornees e Arameo, que, en algún momento dado, le habían concedido a él y a su mujer durante sus vidas ${ }^{43}$. Estos hechos podrían explicar, por tanto, que al margen de lo que se pudiese entregar a San Martín como uno más de esos monasterios de la ciudad de Santiago y de sus alrededores a los que Marzoa dejó un pequeño legado pío, el monasterio benedictino no figure entre las instituciones más favorecidas por el testador. Solo habían pasado un par de años y las decisiones tomadas por los religiosos habían comprometido seriamente su fundación de 1495. Por ello, resulta sumamente expresivo que sus últimas voluntades puedan ser leídas como un fiel reflejo de ese enfriamiento y de la ruptura de las relaciones entre el notario y una de las principales instituciones eclesiástica de la Compostela bajomedieval ${ }^{44}$.

Sin embargo, hay otra institución que figura en las últimas voluntades de Lope Gómez de Marzoa. Se trata del monasterio cisterciense de Santa María de Aciveiro, situado en la Tierra de montes. En este caso, aunque declara que actúa por descargo das almas do dito mestre Guillén y de mina madre y mya, la naturaleza de la mención ya no es la de entregar un legado pío como los anteriormente mencionados. Lo que hace el testador es devolver dos cálices que habían sido del monasterio y que un abad enpeñó a mestre Guillen, meu amo, que deus aja, que pesarían asy cinco marcos de plata dourados.

Organizado todo lo referente al cuerpo y al alma, resultaba esencial organizar la transmisión del patrimonio restante. En ese sentido, cabe destacar un primer

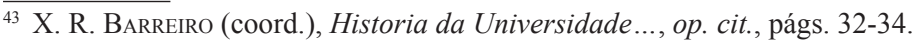

${ }^{44}$ Que San Martín Pinario desapareciese de las últimas voluntades de Marzoa en 1501 no implica que no estuviese presente en el testamento que otros autores refieren con fecha del 5 de noviembre de 1496. De hecho, Fernando López Alsina señala que "en su testamento Marzoa mandó que se construyera una capilla dedicada a San Gregorio, en la que había sido sala capitular [de San Paio de Antealtares]. Legó todos sus bienes a esta capilla y quiso que los monjes de San Martín, que serían los administradores, pusieran en ella uno o dos capellanes, según lo permitieran los réditos de los bienes. Los capellanes tenían a su cargo celebrar misas y oficios divinos en el Colegio". F. LÓPEZ Alsina, "Marzoa, Melgar, Muros, Fonseca...", op. cit., págs. 805-806. Es muy probable que ese testamento anterior sea el que, un día antes de la muerte de Marzoa, fue a buscar Alonso de Camba, criado del notario compostelano, al monasterio de San Martín, a donde el abad frey García de Astodillo le dio el testamento que tenya en guarda del dicho Lope Gómez. Esas últimas voluntades parece que quedaron en poder de Francisco de Treviño, después de que Mayor Fernandes o por su mandado alguno de los que estauan presentes tomaron el dicho testamento y lo entregaron al dicho Francisco Trevyño en sus manos, el qual lo resçibió en sus manos y poder y se llegó con el a la ventana de la cámara donde jazían el dicho Lope Gomes y començó de leer entre sy. AHUS, Protocolos, S-7, fols. 282r.-282v. No obstante, ha de recordarse que fue en su última noche de vida, en la que Marzoa otorgó sus últimas y definitivas disposiciones testamentarias, a tenor de lo que afirman los testigos presentes en ese momento. AHUS, Protocolos, S-3, fols. 98r-103v.
} 
capítulo: la concesión de legados a favor de particulares. Lo escueto del testamento de Lope Gómez de Marzoa no nos permite en modo alguno trazar la seguramente amplia red de relaciones sociales que mantuvo a lo largo de su vida. De hecho, son muy limitadas las menciones a personas concretas beneficiadas con alguna de sus mandas. En el caso del mercader vasco, Juan Martínez, procedente del pueblo costero de Guetaria, la relación parece ser meramente profesional. A él le otorga 2.000 pares de blancas por descargo de çiertas pypas que le tomé y por descaminado quando tuve las rentas del obispado de Tuy. Es la única mención que se contiene en su testamento sobre las actividades económicas realizadas a lo largo de su vida, bien documentadas, por otra parte, como se ha visto con anterioridad. La mención a este mercader vasco responde en gran medida a la práctica habitual de muchos testadores de dejar junto a sus últimas voluntades una relación de deudas y deudores.

En el caso de Marina, hija de Gonzalo de Romay, se le destina un legado de 4.000 pares de blancas para su casamiento. Se trata de una costumbre recurrente en muchos de los testamentos coetáneos. Con asiduidad eran legados otorgados a favor de criados y dependientes que, a través de estas concesiones, veían facilitado su acceso al mercado matrimonial. De todos modos, en este caso se trata de la hija de un conocido mercader compostelano, lo que permite hablar de las relaciones de amistad y alianza entre Lope Gómez de Marzoa y otros burgueses de la ciudad. Diferente es la mención a Ruy González, del que se dice que moró conmigo, por lo que posiblemente sí se trataría de un dependiente y servidor del testador. Sin embargo, en este caso se establece que los 2.000 pares de blancas que se le destinan solo se le den en caso de que acudiese -entendemos que a la ciudad de Santiago- en el tiempo de tres años a contar desde el momento de su fallecimiento. De lo contrario, los mil pares de blancas se dean en limosna por misas y los quinientos al monesterio de Santo Domingo y los otros quinientos a San Françisco que digan en misas. Es decir, el legado a un particular podía terminar convirtiéndose en un nuevo legado pío en beneficio de su alma. Además es de destacar de nuevo la particular atención hacia los mendicantes, situando en igualdad de condiciones a los dominicos y franciscanos, sin mostrar, por tanto, preferencia por una Orden sobre la otra.

Finalmente, y antes de nombrar a los herederos, Lope Gómez de Marzoa no olvida entregar a su mujer, Mayor Fernández, un importante legado con bienes muebles. Se trata de

toda a myna parte do axuar de casa, eçebto foro y plata, y toneles con o vyno, y tapaçeria y más le mando todas as joyas de ouro y plata, de çintas y anillos y pedras, eçebto ouro y plata amonedada, y toda la otra plata de jarros y platos y taças y escudillas y toda la 
otra plata y ouro que no sejan sus joyas", eso sí, "con condiçion que no leven ni demanden a diezma, y sy la demandare y quisyere llevar, que no aya ni llieve ninguna cosa desto que le mando.

Resulta importante destacar que Lope se está refiriendo a su parte del ajuar doméstico, lo que implica que la otra parte ya le pertenecía por derecho a su mujer. Las disposiciones testamentarias del notario compostelano solo hacen referencia a sus bienes, aunque, tal y como se ha podido comprobar, algunas actuaciones realizadas a lo largo de su vida sí se referían, al menos en parte, al patrimonio de ambos, presumiblemente a los gananciales. De ahí que, tras el fallecimiento del testador, su viuda se decidiese a pleitear por lo que entendía que le correspondía.

Una de las cuestiones más importantes a la hora de otorgar testamento era el nombramiento de los herederos. En este caso, además, mis herederos universales en todos mis byenes muebles y rayzes mina manda conplida coinciden con los llamados a ser también sus cumplidores testamentarios. Se trata de Françisco Treviño, regidor desta çibdad de Santiago, y a Ruy de Perera, mi criado, quien desempeñaba el oficio de notario. En su doble condición de herederos y testamentarios, ambos tuvieron que hacer frente a diversos pleitos por la herencia de Lope Gómez de Marzoa ${ }^{45}$. El porqué de su nombramiento como responsables del cumplimiento y de la herencia del testador hay que situarlo en el marco de la proximidad y confianza que sin duda existiría entre ambos hombres y Lope Gómez de Marzoa. La amistad y las experiencias e intereses compartidos explicarían esta decisión. Sin embargo, no podemos dejar de extrañarnos por la decisión tomada por el testador. Al menos, no resulta habitual y, de hecho, en la Galicia de finales de la Edad Media no es raro que los burgueses sin hijos optasen por nombrar como herederas de sus bienes a sus mujeres ${ }^{46}$. No es este el caso. Por

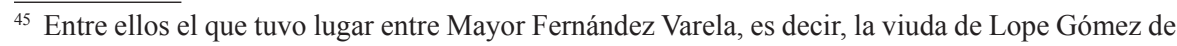
Marzoa, y Francisco de Treviño y consortes, durante el cual tuvo lugar la presentación de las últimas voluntades como prueba documental por parte de Francisco de Treviño y Ruy de Pereira. ARCh $\mathrm{Va}$, Pleitos Civiles, Alonso Rodríguez (F), Caja 657, 1.

${ }^{46}$ Fue el caso del mercader Arnao de Frisia, vecino de Santiago, quien otorgó su testamento en la ciudad de Ourense en 1489. En el mismo nombra como miña universal herdeyra de todoslos outros meus beens que aqui mandados non ey a miña moller Aldonça Gonçalves, asy mobeles como rayzes que ao de presente teño e ajo, asy enna çibdade de Santaigo e Tuy e Ourense e que me sejan devidos (...) et ha faço conpridora deste dito meu testamento e exequias e pias cabsas. Anselmo López CARREIRA, A cidade de Ourense no século XV. Sociedade urbana na Galicia baixomedieval, Ourense, Deputación Provincial de Ourense, 1998, pág. 654, doc. 22. También el impresor y librero Rodrigo de Lavandeira optó por la misma solución en 1510, cuando otorgó sus últimas voluntades en Ourense: alço, coostytuio e nombro por mi universal heredera a la dicha María Fonso, mi muger, a la que también nombra como cumplidora testamentaria junto a Blas Moreiro, primo de ella, y a Gonzalo
} 
ello, se intuye que, más allá de lo que se dice en el testamento, Lope Gómez de Marzoa posiblemente había acordado con dos hombres de su confianza el destino final de sus propiedades. Para tratar de obtener respuestas a este interrogante es necesario analizar nuevamente las informaciones que nos aporta el documento en el que declararon una serie de testigos sobre los últimos momentos del testador $y$, entre ellos, su propia viuda ${ }^{47}$.

Uno de los testigos, en concreto, el sastre Lope de Queizán responde cuando le preguntan si Lope Gómez confió a Treviño su alma y que distribuyese su hacienda en legados y mandas pías que no lo sabe pero que cree ser verdad porque este testigo sabe que tenía muy grand y estrecha amistad y comunicaba sus cosas y secretos el uno del otro y andaba muchas veces juntos. También era muy próxima la relación con su otro heredero y cumplidor pues se dice que: Lope Gomes tenía muy grandísima afición y a mor a Ruy de Pereyra, y hera su criado y confiaba del todas sus cosas, dixo que hera asy la verdad y que él le fiso onbre. Además, el testigo señala que Treviño y Ruy de Pereira fisieron donaçion de la fasienda del dicho Lope Gomes al cabildo e iglesia de Santiago que fue por cabsa que el dicho Lope Gomes se lo avía rogado y encargado su anima. Posiblemente ahí esté la clave del nombramiento de estos dos hombres como sus cumplidores y herederos. Más que beneficiarlos a ellos, confiaba en que uno y otro velarían por sus intereses y, por tanto, ante la ausencia de descendientes, la inversión patrimonial en obras pías adquiría una importancia capital.

El herrero Juan de Betanzos nos ayuda a conocer un poco mejor la actuación de estos dos hombres. Tras la muerte del testador, el dicho Ruy de Pereyra tomara las llaves a la dicha muger del dicho Lopo Gomes y puso en recabdo la plata y otras cosas que allí avía. Ratifica así mismo la amistad con el difunto señalando que Ruy de Pereira era querido como hijo y que con Francisco de Treviño le unía una gran amistad. Sin embargo, lo anormal de este nombramiento incita a los pesquisidores a plantear una última cuestión sy avía visto alguna mala presunción o conjetura por donde se presumiese alguna cosa que no fuese de voluntad del dicho Lope Gomes. A este respecto, el testigo declara que no vio nada extraño y, aún más, dice que se comentó delante del testador que ambos hombres quedaban como herederos y que no vio que Lope contradijese dicha afirmación. Incluso advierte que estaba presente Ares Peres que hera casado con una su parienta del dicho Lopo Gomes y el mismo fyrmo la manda. Parece, por tanto, que todos conocían la última voluntad del testador a pesar de otorgarse mediante un testamento cerrado. Su propia mujer estaba al tanto de lo que sucedía: dixo su muger

Fernández, escribanos y vecinos de la ciudad de Ourense. Olga Gallego Domínguez, "O primeiro impresor ourensán: Rodrigo de Lavandeira", Boletín Auriense, XXXVI (2006), págs. 113-114.

${ }^{47}$ AHUS, Protocolos, S-3, fols. 98r-103v. Veáse doc. 2 del apéndice documental. 
del dicho Lope Gomes a vozes altas que las oyeron todos los que estavan en la cámara y el dicho Lopo Gomes con ellos (...) lo desya alto, oyd, notario, asentad que dice Lopo Gomes que aparta todos sus parientes en cinco soldos, sin que nadie lo contradijese. De hecho, eso mismo declara Gonzalo de Melide, quien añade que, aunque estaba algo apartado, oyo desir al dicho Lopo Gomes por su boca lo de los dichos cinco sueldos.

Que el nombramiento de Treviño y Pereira como herederos tenía como objetivo último el trasvase de propiedades a favor de la Iglesia compostelana también se intuye del testimonio ofrecido por Antonio Rodríguez, del que Marzoa era feligrés. El sochantre declara que

hablara un dia antes que el dicho Lopo Gomes fallesçiese con Alonso de Camba, vecino desta dicha çibdad, por que hera su muy yntymo amigo del dicho Lopo Gomes para que le consejase que fisyese su testamento y que dexase personas que fuesen de buena conciencia para que dispusyesen de su fasyenda a servicio de Dios.

De este modo se entiende la peculiar institución de herederos por parte del notario compostelano. Además, Antonio Rodríguez declara que

oyera desir este testigo a la mujer del dicho Lopo Gómez que el dicho Francisco Treviño no podía faser otra cosa de la dicha fasyenda salvo lo que fizo que es darla a la iglesia y cabildo para faser alguna memoria del dicho defunto porque asy lo avía acordado con él el dicho Lope Gomez.

Incluso, un último testigo, un zapatero y vecino de Santiago llamado Martín, declaró unos días más tarde que tyene por cierto que se confio dellos para que ellos diesen y entregasen la dicha su fasienda y herencia a la dicha iglesia de Santiago. Y, además, aún añade un último dato de interés: había oído de algunas personas que el testador tenía en voluntad de hacer sepoltura dentro de la dicha iglesia y en la capilla de Sant Juan y de faser alargar la dicha capilla. No caben dudas sobre el modo de actuar del testador.

Aún así, el testimonio más contundente respecto a la estrategia de Lope Gómez de Marzoa es el ofrecido por su mujer el 26 de octubre de 1501:

dixo que sabia muy bien y esta hera la verdad que la voluntad e yntinçion del dicho Lope Gómez fue de dexar todos sus bienes y 
herencia a Dios nuestro señor y a la santa iglesia de Santiago y non a Francisco Treviño ni a Ruy de P<er>eyra y que non enbargante que Francisco Treviño y el dicho Ruy de $P<$ er $>$ eyra estén escriptos en el dicho testamento por herederos, que fue con yntinción y confiança que dellos tuvo que dispornía de su fasienda y la daría a la dicha santa iglesia de Santiago para que fisiese memoria para siempre por su anima.

Se trataba de una decisión meditada:

muchas veces hablando con el dicho Lopo Gomes su marido, le dixera y declarase voluntad ser aquella y que también le oyo desir que tenía mucha deboçion con la capilla de San Juan que esta dentro de la dicha santa iglesia de Santiago do el hera feligres y que conosció de su voluntad asy mismo de dexar alguna parte de su fasyenda para ella (...) y que sus bienes non quedasen salvo segund que dicho es (...) porque ella sabe que el dicho Lopo Gomes no tenía yntención de dexar al dicho Ruy de $P<$ er $>$ eyra por heredero, salvo sy ella misma non ge lo dixera que confiase del su anyma y que por esta cabsa se movió a dexarle por heredero y non para que llevasen el ni el otro los bienes.

Es decir, la propia Mayor Fernández comparte e influye en su marido, recomendándole el nombramiento de uno de sus herederos y cumplidores. Seguramente la propia viuda había pactado con él su papel secundario en un testamento que tenía como objetivo último entregar el remanente de su patrimonio, tras la concesión de una serie de legados píos y a particulares, a favor de la Iglesia compostelana. Resultaba posiblemente más operativo que fuesen otros, amigos y personas próximas a él, los que se responsabilizasen de la tarea. Personas que, no hemos de olvidarlo, sabían moverse con soltura por la sociedad compostelana.

Precisamente, no es la primera vez que el regidor compostelano Francisco de Treviño aparece con un papel destacado en las últimas voluntades de un miembro de las élites compostelanas. En el testamento otorgado en 1489 por el tenente de A Rocha y también regidor de Santiago, Álvaro Sánchez de Ávila, Francisco Treviño fue instituido como uno de sus cumplidores testamentarios, además de ser voluntad del testador 
que de Beliça, mi nieta, fija de Catalina Sanches, mi fija, e de Juan de Presedo, su marido que fue, y defunto, tenga la tutela e guarda ansy dellas conmo de sus byenes Françisco Trebino, regidor desta çibdad de Santiago, al qual conmo a mi buen e especial amigo ge la encargo, non mas ni menos que sy fuese fija propia, mia o suy $a^{48}$.

Más allá de su papel como cumplidor y de actuar como tutor de la nieta del testador, Isabel Sánchez de Ávila, ha quedado constancia de la preocupación de Treviño por la conservación de la memoria de Álvaro Sánchez en la institución de dos aniversarios por su alma en la catedral compostelana ${ }^{49}$. Todo ello permite confirmar la importancia de las conexiones personales y de las redes de amistad y confianza existentes entre las oligarquías urbanas de la Compostela de finales del siglo XV. Se trataba, claro está, de dos hombres unidos por la amistad, pertenecientes a la élites urbanas compostelanas y que, de un modo u otro, representan las nuevas inquietudes culturales del momento, que se expresaban de formas muy diversas, pudiendo abarcar desde la promoción de determinadas instituciones educativas hasta el contacto directo con la cultura letrada a través de la posesión de nutridas bibliotecas.

De todos modos, lo que se desprende del análisis detenido del testamento de Lope Gómez de Marzoa es que nos encontramos ante un documento escueto en el que se recoge lo esencial sobre el destino del alma, el cuerpo y el patrimonio del testador, sin entrar en una pormenorización de detalles. Ello también se refleja en las consideraciones finales destinadas a ratificar que se trata de su manda, testamento y postrimera voluntad, revocando las otras mandas y codicilos que pudiese haber otorgado con anterioridad ${ }^{50}$. No se olvida de apartar a sus parentes y parentas con los cinco sueldos habituales y de valorar su manda en 1.000 doblas de oro, que habrían de pagarse, en caso de atentar contra sus últimas voluntades, la mitad a sus herederos y la otra mitad a la cámara del señor arçobipso de Santiago. Todo ello fue otorgado ante el notario público y testigos, dando fe el sochantre Antonio Rodríguez y Ares Pérez de Baruta.

\footnotetext{
${ }^{48}$ X. M. SÁnchez SÁnchez, "Don Álvaro Sánchez de Ávila...,", op. cit., págs. 182-183, doc. 12.

${ }^{49}$ X. M. SÁnchez SÁnchez, "Don Álvaro Sánchez de Ávila...”, op. cit., págs. 191-193, docs. 15, 16 y 18.

${ }^{50}$ Tal vez pensaba expresamente en esa otra otorgada en 1496 en la que había dispuesto la fundación de una capilla dedicada a San Gregorio, cuya administración recaería en los monjes, otrora aliados, de San Martín Pinario. F. López Alsina, "Marzoa, Melgar, Muros, Fonseca...”, op. cit., págs. 805-806.
} 
Es de destacar que, después de su muerte, los testigos que declaran sobre el otorgamiento y contenido de sus últimas voluntades insisten precisamente en evocar el apartamiento que hizo de sus parientes respecto al acceso a la herencia con los tradicionales cinco sueldos. Sin duda, lo excepcional de nombrar como herederos y albaceas a dos hombres que, pese a estar unidos estrechamente al testador por los vínculos de amistad, no eran parientes, podía convertirse en fuente de conflictos y dejar paso a que sus parientes pleiteasen por la herencia, como así sucedió. Si bien los tribunales acabaron por nombrar como heredero directo de Marzoa a su pariente Alonso Ares de Ocampo -cumpliendo con una legalidad que trataba de proteger los derechos de los familiares a la herencia a pesar de que no se tratase de descendientes o ascendientes, sino de colaterales-, por el momento parece necesario señalar que las últimas voluntades de Lope Gómez iban por otros derroteros. La infrecuente decisión de nombrar como herederos a sus cumplidores no fue sino consecuencia del deseo de Marzoa de dar otra salida a su herencia. Frente a sus parientes, la capilla de San Juan -y consecuentemente, su alma- sería en gran medida la beneficiaria última de su hacienda y, en esa estrategia, Treviño y Pereira serían los encargados como cumplidores y "herederos provisionales", de llevar a cabo sus plantes. Solo así es posible comprender el contenido de su testamento y las declaraciones de su viuda y otros testigos que señalan que Treviño no podía hacer otra cosa de la hacienda salvo lo que hizo: darla a la Iglesia y cabildo de Santiago. No obstante, esta estrategia no salió bien, de ahí los pleitos que surgieron a su muerte y que dificultaron el cumplimiento exacto de las últimas voluntades de Lope Gómez de Marzoa.

\section{UNA HERENCIA EN DISPUTA: LOS PLEITOS ANTE LA CHANCILLERÍA DE VALLADOLID}

Aunque nos interesa destacar la aparición de un conjunto de disputas en torno a la herencia de Lope Gómez de Marzoa, es necesario dejar constancia de que, como típico hombre de negocios, Marzoa mantuvo a lo largo de su vida varios pleitos en la Chancillería de Valladolid, algunos con sus adversarios en el negocio fiscal, como el que le enfrentó con el principal arrendador de las rentas del reino de Galicia, Ruy Martínez de Carballido, otros por las cantidades que se le adeudaban como resultado de su participación en el arrendamiento y recaudación de las rentas reales, y finalmente los que tuvieron que ver con el reparto de la herencia, que son los que aquí más nos interesan.

En el primero de los casos, el demandante Ruy Martínez de Carballido, llevaba al notario Marzoa ante los alcaldes de la Chancillería de Valladolid, acusándole de haber sustraído los documentos necesarios para efectuar ciertas pujas en las rentas del arzobispado de Santiago de los años 1488-91. Por este motivo, le reclamaba el pago de 5.000 doblas de oro, cantidad en la que se estimaban las pérdidas 
ocasionadas al no haber efectuado la puja del cuarto, más otros 2.000 .000 de maravedíes por los beneficios que podría haber obtenido en la puja de las rentas. Ante la dificultad para resolver el asunto, el pleito se remitía a la Contaduría Mayor de Cuentas, dándose por concluido en la Chancillería, sin que tengamos noticia de la resolución final del mismo ${ }^{51}$.

El segundo de los pleitos, iniciado en septiembre de 1501, enfrentó a la viuda de Lope Gómez de Marzoa, Mayor Fernández Varela, con la viuda y herederos del regidor madrileño Fernando de Madrid, quien había actuado como su factor en el arrendamiento de las rentas de los partidos de Lugo y Mondoñedo de los años 1498-99. En este caso, la viuda del notario Marzoa reclamaba $78.600 \mathrm{mrs}$ por las alcabalas que habían estado a cargo de su marido en los partidos fiscales mencionados. En relación con el caso, los alcaldes de la chancillería sentenciaban a favor de la viuda de Lope Gómez, que debía percibir de los herederos de Fernando de Madrid un total de $35.000 \mathrm{mrs}$, de los $70.000 \mathrm{mrs}$ que habían quedado debiendo a su marido ${ }^{52}$.

El tercero de los pleitos, relativo a la herencia del notario compostelano, enfrentaba nuevamente a la viuda de éste, Mayor Fernández Varela, con el notario Ruy Pereira y con el regidor santiagués, Francisco de Treviño, precisamente los albaceas testamentarios que Lope Gómez había designado para que se cumplieran sus últimas voluntades. Las declaraciones presentadas por los testigos del pleito que la viuda de Lope Gómez de Marzoa mantuvo con ambos nos informan acerca de las distintas actividades profesionales que desarrolló Lope Gómez de Marzoa a lo largo de su vida, así como de los niveles de renta y patrimonio que poseía junto a su mujer Mayor Fernández, y cómo la herencia quedó dividida después de su muerte.

En este sentido, algunos de los testigos señalaban como el notario Lope Gómez de Marzoa había tenido arrendadas las doceavas partes de las rentas reales del partido de Santiago y Tui durante tres años en colaboración con el pontevedrés Pedro Cruu y Fernando de Cuenca, y estimaba las ganancias que habrían podido obtener cada uno de ellos en unos $100.000 \mathrm{mrs}$. anuales. Igualmente, señalaban que a la fecha de su muerte, se habían quedado debiendo a Lope Gómez de Marzoa, importantes cuantías de maravedíes que al parecer eran difíciles de recaudar ${ }^{53}$.

\footnotetext{
$\overline{51}$ ARChVa, Registro de Ejecutorias, Caja 24, 18, Escribanía de López Julián.

52 ARChVa, Registro de Ejecutorias, Caja 187, 21, Escribanía Quevedo: La carta ejecutoria del pleito litigado entre la viuda de Lope Gómez de Marzoa y la parte de Fernando de Madrid, fechado en Valladolid, el 16 de enero de 1504, obligaba a la mujer e hijos de éste último a satisfacer 5.035 mrs. por los gastos y costas generados en el pleito que había tenido lugar entre ambas partes.

53 ARCh $\mathrm{Va}$, Pleitos Civiles, Alonso Rodríguez (F), Caja 657, 1.
} 
En las vísperas de su muerte, el notario Lope Gómez de Marzoa era titular de una gran fortuna que reunía, no solo los juros que percibía sobre las rentas reales, sino una gran cantidad de bienes muebles e inmuebles repartidos entre las ciudades de Santiago, Baiona y Pontevedra, algunos de los cuales poseía junto a su mujer Mayor Fernández Varela ${ }^{54}$.

Uno de los datos más reveladores acerca de la hacienda y patrimonio que poseía Lope Gómez unos años antes de su muerte se contiene en las informaciones de abono que presentaron ciertos testigos durante el proceso de arrendamiento de las rentas de los partidos de Lugo y Mondoñedo de los años 1498-99. Las declaraciones prestadas por los testigos califican a Lope Gómez como uno de los hombres más acaudalados de la ciudad, con unos bienes raíces por un valor aproximado de 1.500.000 $\mathrm{mrs}^{55}$.

El pleito entablado entre la viuda de Marzoa, Mayor Fernández Varela, y los albaceas testamentarios de su marido, el notario Ruy de Pereira y el regidor Francisco de Treviño, constituye posiblemente la mejor fuente de información para conocer la hacienda y patrimonio que poseía el notario Lope Gómez de Marzoa en las vísperas de su muerte, y como se efectuó el reparto de su herencia después de la misma, acaecida seguramente en septiembre de 1501.

En relación con el reparto de la herencia, los testigos señalaban como, fallecido el notario, su viuda Mayor Fernández Varela había quedado en posesión de las casas principales en las que había vivido junto a su marido, situadas en la Rúa de la Azabachería, y valoradas en una cuantía aproximada de 200.000 mrs. Además de estas casas, Mayor Fernández había heredado también la mitad del casal de la Horta y la huerta de la Algalia de Abajo, la mitad de los lugares de Gondomar y Amego, la mitad de los casales de Aguapesada, el foro del lugar de Berreo (sic) que tenía aforado del monasterio de San Martín Pinario y que rentaba unas cuarenta o cincuenta rapadas de centeno al año, a lo que venía a añadirse el solar que había pertenecido a Nicolás de Zamora en la Rúa del Preguntoiro.

Además de los numerosos bienes inmuebles, rústicos y urbanos, que poseía en la ciudad de Santiago y en sus inmediaciones, Lope Gómez de Marzoa era titular también de ciertas casas en la villa de Baiona, ya que con posterioridad a su muerte correspondían a su viuda la meytad de las casas que Lope Gómez hiçiera labrar en Bayona. También en Pontevedra poseía una notable hacienda, concretamente una serie de bienes valorados en 140.000 mrs., que a su muerte

\footnotetext{
${ }_{54}$ Sobre los bienes y patrimonio que poseía Lope Gómez de Marzoa antes de su muerte, véase A. Rubio Martínez, "Un hombre de negocios...", op. cit., págs. 127-142.

${ }^{55}$ AGS, EMR, leg. 66, fols. 244 y 267: Según la información proporcionada por los testigos, los bienes raíces del arrendador y recaudador mayor Lope Gómez de Marzoa se estimaban en 1.469.000 mrs., $1.508 .000 \mathrm{mrs}$. y $1.517 .000 \mathrm{mrs}$.
} 
quedarían divididos entre su viuda y el cabildo compostelano. Los testigos señalaban también que Lope Gómez junto a su socio Gómez Arias, era titular de una nao atracada en un puerto del reino de Galicia, cuyo valor se estimaba en unos 74.000 mrs., una cantidad que a su muerte quedarían divididos entre su viuda y el cabildo catedralicio, $37.500 \mathrm{mrs}$. a cada parte, más el diezmo de la parte correspondiente al cabildo, para su viuda en concepto de arras.

Del mismo modo, y en relación con sus bienes muebles, los testigos no dudaban en referirse a los muchos bienes muebles, pan, vino y alhajas de casa y otras muchas cosas y tapicería que quedara de Lope Gómez..., cuyo valor se estimaba en un total de $120.000 \mathrm{mrs}$. que, tras su muerte, se repartirían por mitad entre su viuda y el cabildo catedralicio, correspondiendo una vez más a la primera el diezmo de la cuantía asignada al cabildo catedralicio ${ }^{56}$.

Lo hasta aquí visto permite comprobar que en una primera fase el reparto de la herencia de Lope Gómez de Marzoa se efectuó con total normalidad. Sin embargo el problema se planteó a partir de las deudas que el notario Lope Gómez había contraído con la Hacienda Regia por el arrendamiento de las rentas de los partidos de Lugo y Mondoñedo de los años 1498 y 1499.

Con posterioridad a 1501, fallecido ya Lope Gómez de Marzoa, la Hacienda Real reclamaba a su viuda, Mayor Fernández Varela, las cantidades que había dejado pendientes su marido, lo que daría lugar a un largo pleito con los albaceas testamentarios del mismo, el regidor Francisco de Treviño y el notario Ruy de Pereira.

El problema principal se desató por el juro de Baiona con el que Marzoa había dotado al Estudio Compostelano, del que ahora su viuda reclamaba una parte. La solución llegaba en 1512 con una sentencia de la Chancillería de Valladolid por la que se asignaba una parte del juro de Baiona -11.000 mrs.- a Mayor Fernández Varela, quedando la cantidad restante $-9.000 \mathrm{mrs}$.- para el Estudio Compostelano. A partir de esta sentencia, se ordenaba al obispo de Mondoñedo, Diego de Muros II, entregar a la viuda de Lope Gómez, la parte que le correspondía del juro de Baiona que había pertenecido a su marido, y unos años después, en 1516, Carlos I confirmaba estos $9.000 \mathrm{mrs}$. de juro de heredad al Estudio Compostelano ${ }^{57}$. Con posterioridad a esta fecha, Mayor Fernández de Varela debió ceder los $11.000 \mathrm{mrs}$. del juro de Baiona a su segundo marido, el mercader coruñés Alonso de Salamanca, ya que en la segunda década del siglo XVI, el propio Alonso de Salamanca decidía

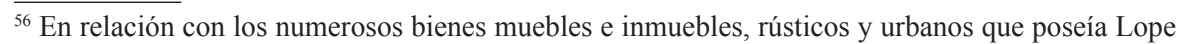
Gómez de Marzoa en las ciudades de Santiago, Pontevedra y Baiona, véase A. Rubio Martínez, "Un hombre de negocios...", op. cit., págs. 127-142.

${ }^{57}$ Algunas noticias sobre este asunto en AGS, CMH, Contaduría de Mercedes, 36, 25 y RGS, Burgos, 11 de septiembre de 1512, fol. 251.
} 
devolver el juro a su esposa, con la condición de que a su muerte lo donase a la cofradía de los disciplinantes de la ciudad de San Francisco ${ }^{58}$.

Pero no sólo fue la viuda de Lope Gómez la que reclamó parte de la herencia de su marido, sino que también algunos parientes próximos al notario como Alonso Ares de Ocampo, apelaron en la Chancillería de Valladolid contra los albaceas testamentarios de Lope Gómez. Finalmente, la sentencia de los jueces de la Chancillería nombraba como heredero directo de los bienes de Lope Gómez a Alonso Arias de Ocampo, al tiempo que ordenaba a Ruy de Pereira y Francisco de Treviño la entrega en un plazo de treinta días de los bienes que hubiesen quedado del notario con los beneficios que hubiesen generado hasta la fecha en que dichos bienes le hubiesen sido restituidos ${ }^{59}$.

\section{CONCLUSIONES}

El destacado papel que tuvo el notario Lope Gómez de Marzoa en la Compostela de finales de la Edad Media justifica la curiosidad que ha despertado este personaje entre todos aquellos que se han interesado por conocer los orígenes de la Universidad de Santiago de Compostela y también los que han pretendido clarificar el panorama cultural de la Galicia del siglo XV. Además de promover la fundación de dos iniciativas educativas, tanto la de 1495 como la de 1501, su trayectoria como hombre de negocios lo convierte en una figura del máximo interés para conocer los comportamientos socioeconómicos e inquietudes culturales de las élites urbanas gallegas bajomedievales.

Ahora, además de conocer sus últimas voluntades -las cuales responden a la normalidad de la práctica testamentaria ordenando todo lo relativo al cuerpo, al alma y al patrimonio-, se ha podido avanzar en la clarificación de sus orígenes familiares. Estos, junto con su trayectoria vital, permiten dar por cierta la consideración de que Marzoa era un ome poderoso y muy emparentado en la ciudad de Santiago. El notario y regidor compostelano tenía entre sus familiares y amigos a varios regidores compostelanos de la segunda mitad del siglo XV: su padre - ¿O tal vez padrastro?-Martín Guillén; su amigo, heredero y cumplidor testamentario Francisco de Treviño, y los maridos de su prima Inés García, Juan Castellanos y Álvaro Sánchez de Ávila. Además, contaba con firmes aliados entre el clero compostelano, como se puede observar tanto en la fundación de 1495 -para la que recibió el apoyo de los monjes benedictinos de San Martín Pinario-, como

\footnotetext{
$\overline{58}$ AHUS, Protocolos S-7, fols. 279r.-279v., s.d.

59 ARChVa, Registro de Ejecutorias, Caja 192, 5: Ejecutoria del pleito litigado por Alonso Arias de Ocampo, vecino de Santiago de Compostela (A Coruña), con Francisco de Treviño, vecino de Santiago, sobre la herencia de Lope Gómez de Marzoa.
} 
en 1501, cuando el patronazgo del Estudio Viejo fue compartido con el deán don Diego de Muros III y el obispo homónimo don Diego de Muros II. No es de extrañar que esta proximidad con las élites eclesiásticas compostelanas terminase con la entrega de sus bienes a la Catedral, donación que habría sido canalizada a través de la figura de sus amigos Francisco de Treviño y Ruy de Pereira.

Podemos considerar, por tanto, que Lope Gómez de Marzoa constituye un buen ejemplo de hombre de negocios, así como una figura representativa de los orígenes, las relaciones y, en gran medida, las inquietudes testamentarias de las élites urbanas que acapararon las regidurías en la Compostela de finales de la Edad Media.

\section{APÉNDICE DOCUMENTAL}

1501, septiembre, 28.- Santiago de Compostela.

Testamento de Lope Gómez de Marzoa, marido de Mayor Fernández de Varela, en el que nombra por herederos universales de sus bienes a Francisco de Treviño, regidor de Santiago y a Ruy de Pereira, notario y criado suyo.

VALLADOLID, ARCH, Pleitos Civiles, Escribanía de Alonso Rodríguez (F), Caja 657-1, papel, traslado notarial de Alvar Núñez, escribano de la Audiencia de Santiago, sobre el testamento de Lope Gomez de Marzoa, presentado por Francisco de Treviño y Ruy de Pereira en la Audiencia de Santiago el 13 de julio de 1502, ante el gobernador y alcaldes mayores, castellano y gallego, letra procesal.

En la çibdad de Santiago, a veynte y ocho días del mes de setienbre, año del nasçimiento de nuestro señor Ihesuchristo de mil y quinientos y un años, de noche dentro de la casa de morada del honrrado Lope Gomez de Marçoa, notario y vesyno de la dicha çibdad de Santiago que estan y son sytas dentro de la Rua de la Azevecharia de la dicha çibdad y jasyendo\| el dicho Lope Gomez enfermo en una cama de dolençia y enfermedad de que se fallesçio y estando ende presente Antonio Rodrigues, sochantre en la santa iglesia de Santiago, syncura y capellan, y en presençia de mi el publico notario y testigos de yuso escriptos, el dicho Antonio Rodrigues, suchantre, tenia en su mano dos pliegos de papel y coxidos parte dellos escriptos segund vy y por ante mi el dicho notario y testigos de yuso escriptos el dicho sochantre fizo pregunta al dicho Lope Gomez que estava echado en la dicha cama: vos Lope Gomez otorgays esta manda que yo tengo en la mano por vuestra manda y testamyento y el dicho Lope Gomez dixo: sy otorgo. Y yo el dicho notario tome los dichos dos pliegos de papel escriptos parte dellos que asy tenyan el dicho Antonio Rodrigues, Agostín después de dichas las dichas palabras por el dicho Antonio Rodrigues al dicho Lope Gomes y asy\| enbueltos los dichos dos pliegos de papel, parte dellos escriptos, yo el notario le fize preguntar al dicho Lope Gomez vos otorgays esta escriptura por vuestra manda y testamento, ultima y postrimera voluntad y el dicho Lope Gomez dixo y respondio syn que le fuese leyda delante: esta otorgo yo por mi 
manda y testamyento, ultima y postrimera voluntad y reboco y doy por ninguna y de ningun valor todas las otras y qualesquier mandas y testamientos y codiçillos que fasta oy aya y tenga fechas, para que non valgan en juisyo ni fuera del salvo esta que agora doy por mi manda y testamiento ultima y postrimera voluntad y luego el dicho Françisco Trevyño dixo al dicho Lope Gomez: vos rogays Antonio Rodrigues que firme por vos este escripto de manda y el dicho Lope Gomes dixo y porque non puedo firmar ruego Antonio Rodrigues que la firme por mi de su nombre, presentes a ello presentes\| por testigos el dicho Antonio Rodrigues y Ares Peres de Baruta que en ella firmaron sus nonbres y Martino de Fajeyras çapatero, y Juan de Betanços, ferrero, y Lope de Queyçan, xastre, y Gonçalo de Melid, corregidor, vecinos de Santiago, de la qual dicha escritura de manda que arriba se haze mençion su tenor de verbo ad verbo es lo syguiente:

En el nombre de Dios, padre y fillo y esperitu Santo, tres personas y un solo verdadero criador y fazedor de todas las cosas, asy esperituales como tenporales en el qual vyen y verdaderamente yo creo y adoro y le pydo y umillmente suplico que para faser y hordenar a su santo serviçio este auto desta mi manda y testamiento por la su santa clemençia y pyedad me queyera dar su graçia, sejo y entendimiento como seja feyto y hordenado a su servicio y probeyto da mina alma de mi Lope Gómez de Marçoa, || vezino y notario desta çibdad de Santiago, por ende estando doliente de la ynfermedad que a nuestro señor Dios aproubo de me dar y recordandome que teno de morir y temiendome de la fora de la muerte porque tengo de pasar con todo my seso y entendimiento que el nuestro señor aproubo de me dar ofiço y fordeno esta mi manda y testamiento y postrimera voluntad en la forma seguyente:

Primeramente mando myna alma a meu señor y salvador Yhesuchristo que la compro y redimio por su santa y preçiosa sangre y pydo y rogo a la vyrgen Santa María, mi señora y abogada con toda la corte çelestial que queyra por mi rogar a su vendito fillo que no mire a mis grandes maldades y culpas y pecados, mas usando de su clemençia y pyedad me queyra perdonar.

Yten mando enterrar mi cuerpo en la Quintana de Palaçios a la|| puerta del perdon en la sepultura donde esta enterrado mi padre que santa gloria aya. Yten mando que ho dia de mi enterramiento fasta los syete dias me digan cada día diez misas cantadas y rezadas quantos clerigos se podieren aver para las desir. Yten mando que ho día de mi enterramiento y los syete días syguyentes den de comer y de veber a todos los pobres que ovyeren a buscar pan, vyno, carne y pescado como for el dia.

Yten mando a todas las capyllas de la iglesia y çibdad de Santiago y a todos los mosterios, asy da dita çibdad como los de aredor della a cada uno dos libras de azeyte para folme. Yten mando para el lumen del altar del señor Santyago una aroa de azeyte y para el espytar de Santiago dos libres de azeyte y que den más para ho dito espytal en roupa de cama en que duerman los pobres del mill pares de blancas. Yten|| mando a mi capellán por diezmos fioyados y porque me tenga por la mano tresyentos pares de blancas. Yten mando a todos los mosterios do dentro desta çibdad y de aredor della, a cada un çien pares de blancas, a cada uno por que rueguen a Dios por mi. Yten mando al cabyldo de la Yglesia del señor Santiago quatro mill maravedíes pares de blancas y que me digan el día de mi enterramiento y a los syete dias y a los corenta y ano y dya, en cada uno dos ditos dias una misa cantada y que vena sobre mí en sepultura con seu responso y que me fagan tanger as canpanas da dita iglesia, en cada un dos ditos dias. Yten mando a o mosteiro de San Françisco de afor desta dita çibdad çinco mill pares de blancas para la obra y que me digan dos trintanarios por mina anima y de mi padre y madre y de aqueles a que sou obligado. Yten mando a o mosteyro de Santo Domingo de 
apar desta dita çibdad\| para la obra del monesterio otros çinco mill maravedíes de pares de blancas y que me digan otros dos trintanarios. Yten mando a las malatarias de San Lazaro y Santa Marta de Apar da dita çibdad cada una quinientos pares de blancas. Yten mando que la çera y mis honrras y lutos se fagan como mis conplideros vyeren y acordaren que cumple de se faser. Yten mando que los syete días y corenta días y cada año y dia me fagan y digan las misas como el día de mi enterramyento. Yten mando para la obra de San Juan de Calo mill pares de blancas.

Yten ove dos caliçes que fueron do mosteiro de Santa María dazebeyros de feytura do tienpo vello que un abad enpeño a mestre Guillen, meu amo, que deus aja, que pesarían asy çinco marcos de plata dourados, mando que se satisfaga y pague a o dito mosteiro y que no paguen nada de lo que sobrello devyan que hes mays que ha valor dos ditos caliçes y esto les mando\| por descargo das almas do dito mestre Guillén y de mina madre y mya.

Yten mando que den a un mercader vasco, de Guytaria, que se chama Juan Martines dos mill pares de blancas por descargo de çiertas pypas que le tome y por descamynado quando tuvo las rentas del obispado de Tuy.

Yten mando a mina mujer, Mayor Fernández, toda a myna parte do axuar de casa, eçebto foro y plata y toneles con o vyno y tapaçeria y más le mando todas as joyas de ouro y plata, de çintas y anillos y pedras, eçebto ouro y plata amonedada, y toda la otra plata de jarros y platos y taças y escudillas y toda la otra plata y ouro que no sejan sus joyas, con condiçion que no leven ni demanden a diezma, y sy la demandare y quisyere llevar, que no aya ni llieve ninguna cosa desto que le mando.

Yten mando a Marina, filla de Gonçalo de Romay quatro mil pares de blancas para casamyento. Yten mando a Ruy\| Gonçalez que moró conmigo dos mill pares de blancas venyendo dentro de tres años después de mi fallesçimiento y no venyendo que los mil pares de blancas se dean en limosna por misas y los quinientos al monesterio de Santo Domingo y los otros quinientos a San Françisco que digan en misas.

Yten dexo por mis conplidores testamentarios al señor Françisco Treviño, regidor desta çibdad de Santiago y a Ruy de Perera, mi criado, anbos y dos juntamente para que cumplan esta mina manda y testamiento por lo ayo y sin dapno, a los quales dichos Françisco Trevyño y Ruy de Perara, anbos ydos juntamente dexo por mis herederos universales en todos mis byenes muebles y rayzes mina manda conplida, y esta doy y otorgo por mina manda y testamento y postrimera voluntad, y reboco todas las otras mandas y codiçillos que fasta aquí aja feytas, y quiero que no vallan salvo esta mina manda que agora otorgo ante el notario público y testigos y aparto a todos los otros mis parentes y\| parentas en çinco soldos y que amays de mis byenes non se estenda y conto esta mina manda en mill doblas de foro que pague por pena quien quier que contra ella fuere ou pasare a mitad para mis herederos y la otra mitad para la cámara del señor arçobispo de Santiago y en fee de lo qual Antonio Rodrigues, su chantre. Ares Peres da Baruta|. 
1501, octubre, 22 y 26; noviembre, 1.- Santiago de Compostela.

Declaraciones de varios testigos que estuvieron presentes en el momento en el que Lope Gómez de Marzoa otorgó sus últimas voluntades la misma noche de su fallecimiento.

AHUS, Protocolos, S-3, fols. 98r-103v.

En la çibdad de Santiago, en veynte y dos dias del mes de otubre del año del nasçimiento del nuestro señor de mill y quinientos y un años, Gomes Ballo el moço como procurador del cabildo de la Santa Yglesia de Santiago paresçio ante el señor provisor y para en el negocio que toca a la manda de Lopo Gomes de Marçoa, vecino de Santiago, que Dios perdone presentó por testigos at perpetua rey memoria a Lopo de Queyçan, xastre, y a Juan de Betanços, ferrero, y a Antonio Rodrigues, sochantre de Santiago, y a Gonzalo de Mellid, correeyro, vecinos de Santiago, los quales juraron en forma de vida de derecho y so cargo del dicho juramento prometyeron de desir la verdad de lo que supieren çerca desto que son presentados por testigos, testigos que los vieron jurar el señor asystente y Gomes Ballo el mayor y Juan Fernandes y Fernando de la Torre, canónigos de Santiago.

El dicho Lopo de Queyçan, xastre, dixo que lo que sabe deste negocio es lo syguyente: que estando este testigo en casa de Lopo Gomes la noche quel fallesçio que fue llamado para ser testigo del testamento que fasya el dicho Lope Gomes y que le oyera desir por su boca al dicho Lope Gomes quel daua por su testamento y manda la manda que tenía en sus manos Antonio Rodrigues, sochantre, y Jacome de Figueras, notario de Santiago y que aquella hera su testamento y su ultyma y postrimera voluntad y queria que valiese todo lo que en ella estouiese escripto y en qualquier manera estoviese. Y que rebocaua todas las otras mandas y codeçillos que antes ouiese fecho y que aquel daua por fyrme y fuerte y por su manda, testamento o codeçillo o postrimera voluntad.

Fue preguntado este testigo sy al dicho tiempo quel dicho Lope Gomes dixo las dichas palabras sy estaua en su seso, dixo que a su paresçer el dicho Lopo Gomes estaua en su seso aunque estaua con grand ardor y que a el le paresçio quel mismo seso y sano entendimiento que tenia quando sano tenia estonçes, y que le viera desir las dichas palabras con muy buen tyento y le viera comer un caldo y que dixera dadme mas que buen caldo es y que este testigo le viera desir las dichas palabras con tal sentido y seso quel penso que non muriera de aquella dolencia, y que yendose este testigo para su casa le preguntara su muger que tal quedaua el dicho Lopo Gomes y quel respondyera quel non auia de morir de aquella dolençia.

Preguntado sy estaua alli el sochantre por testigo que hera su|| clerigo y presbitero parrochial del dicho Lopo Gomes dixo que el le vido alli estar por testigo y que sabe quel dicho Antonyo Rodrigues, sochantre, hera rector y clerigo parrochial del dicho Lopo Gomes y que sabe que le tenia muy buena voluntad y afiçion y deuocion con el.

Fue preguntado sy sabia el quel dicho Lope Gomes confio de Francisco Treuyño su anyma y le encargo que myrase por ella y por su conçiencia y distribuyese su fasyenda en legatos y mandas pias segund la destribuyo, y dixo que este testigo no lo sabe pero que cree ser verdad porque este testigo sabe que tenya muy grand y estrecha amistad y comunycaua sus cosas y 
secretos el uno del otro y andauan muchas veses juntos, y el uno en la casa del otro y el otro en la del otro, y que por esto cree que pues el dicho Francisco de Treuyño y Ruy de Pereyra fisyeron donaçion de la fasyenda del dicho Lope Gomes al cabildo e yglesia de Santiago que fue por cabsa quel dicho Lopo Gomes se lo avria rogado y encargado su anyma.

Fue preguntado sy sabia que el dicho Lope Gomes tenia muy grandisyma afiçion y amor a Ruy de Pereyra y hera su criado y confiaua del todas sus cosas, dixo que hera asy la verdad y quel le fiso onbre.

Fue preguntado este dicho testigo sy sabe o cree que por la dicha criança y confiança que el dicho Lopo Gomes tenya del dicho su criado Ruy de Pereyra sy se moueria a confiar del su anyma y conçiencia y fasyenda y dixo que creya ser asy verdad por quanto avia cosa del mundo en que quisiesen entender que luego non llamase a Ruy de Pereyra y que por esto este testigo creya a todo su creer que lo que se auia fecho y hordenado por la dicha escriptura y testamento con el dicho cabildo hera verdaderamente fecho y hordenado, y que deste caso esto es lo quel dicho testigo sabia so cargo del juramento que fecho auia y non sabia fyrmar. [Va entre renglones do diz se quantos y testado do desya y se confiaua. Vala que asy ha de desir.]\|

El dicho Juan de Betanços, ferrero, vecino de Santiago, despues de aver jurado en forma deuida de derecho dixo que lo que sabe deste caso es lo syguiente: que este dicho testigo fue llamado y dicho que fuese a ser testigo de la manda de Lopo Gomes en aquella noche quel fiso el testamento. Y que seyendo asy llamado el y Martino de Fageras y Lopo de Cayçan y Ares Peres y el sochantre y otros para que fuesen testigos de la dicha manda, que este testigo entrara en la camara del dicho Lopo Gomes y le oyera desir por su boca estas palabras: quel daua por su manda y testamento, ultyma y postrimera voluntad aquel testamento y escriptura de manda que en sus manos tenya a Jacome de Figueras, notario, el qual notario pregunto al dicho Lopo Gomes sy daua por fuerte y fyrme aquella manda y testamento y el respondio que sy, lo qual dixo dos o tres veses y que asy lo otorgaua y que aquel testamento y manda queria que valiese y todo lo en ella contenido en aquella manera que estaba. Y que revocaua todas las otras mandas y cobdeçillos que antes avia fecho y aquella de la dicha manera que estaba escripta queria que fuese su manda y codeçillo y postrimera y ultyma voluntad para que valiese segund y en qualquier manera que estaua escripta.

Fue preguntado este dicho testigo sy el dicho Lope Gomes estaua estonçes en su sano seso y entendymiento y dixo que a su creer y paresçer todo que el estaua en su seso y sano entendimiento en aquel tiempo y segund que le tenia quando hera sano y que le paresçia que tenia buen tiento y buena manera de desyr y que en aquella ora la señora su muger del dicho Lopo Gomes le diera un caldo y el dixera que hera buen caldo y que le diese mas y que en aquel tiempo estauan alli otros muchos testigos y el sochantre con ellos.

Fue preguntado el dicho testigo sy sabia quel dicho Antonyo Rodrigues, sochantre, hera clerigo parrochial del dicho Lope Gomes y sy hera publico y notorio y dixo que sy.\|

Fue preguntado sy sabia que el dicho Lopo Gomes auia dexado por herederos a Francisco de Treuyño y a Ruy de Pereyra y dixo que el non auia vydo leer la dicha manda, pero que luego en la dicha camara se publico y dixo entre todos como quedauan por herederos el dicho Francisco de Treuyño y el dicho Ruy de Pereyra y luego acabado de otorgar por el dicho Lopo Gomes la dicha manda se dixo publicamente lo susodicho en la dicha camara donde estaua el dicho Lopo Gomes y ante el y que despues de fallesçido el dicho Lopo Gomes, el dicho Ruy de Pereyra tomara las llaues a la dicha muger del dicho Lopo Gomes y puso en recabdo la plata y otras cosas que alli auia. 
Dixo mas este testigo que sabe quel dicho Lope Gomes tenia tan grand amystad y amor con Ruy de Pereyra y con el dicho Francisco de Treuyño que creya ser cosa muy verdadera que por ser el dicho Ruy de Pereyra su criado y su factor y mucho querido como hijo y tanbien por la amistad estrecha que tenia con el dicho Francisco Treuyño se movio a dexarles la dicha hasyenda y herençia, y que por esta cabsa cree este testigo que los fiso sus herederos, y lo tyene por çierto a todo su creer.

Fue preguntado este testigo sy al tiempo que el dicho Lopo Gomes otorgo el dicho testamento sy auya visto alguna mala presunçion o conjetura por donde se presumyese alguna cosa que no fuese de voluntad del dicho Lope Gomes, dixo este testigo que asy al tiempo quel otorgo la dicha manda como luego yncontynente quando se dixo ante todos los testigos que quedauan por herederos los dichos Francisco de Treuyño y Ruy de Pereyra que este testigo no vio ni conosçio presunçion mala alguna ni conjetura, antes le paresçio y agora tyene por çierto a todo su creer que todo se fasya y fiso segund la voluntad del dicho Lopo Gomes y por quel dixo las dichas palabras y otorgo la dicha manda y luego ante este dicho testigo y ante el dicho Lopo Gomes y ante otros testigos se dixo y publico que los susodichos quedauan por herederos establesçidos y el dicho Lope Gomes aunque se le dixo delante y entre todos y ante el que nunca lo contradixo y que sy non fuera su voluntad quando se platycaba asy entre todos, el lo contradixera y que estaua ende presente Ares Peres que hera casado con\| una su parienta del dicho Lopo Gomes y el mismo fyrmo la manda y que pues el dicho Ares Peres estaua casado con su parienta, pues que en la dicha camara por antel se auia platycado que dexaua a los susodichos por herederos y Francisco de Treuyño lo dixo alli en persona de todos, quel dicho Ares Peres, ni el sochantre, sy conosçieran que auya alguna ruyndad non fyrmaran de sus nombres la dicha manda segund la fyrmaron y por esto cree este testigo ser todo verdad.

Dixo mas este testigo que luego que el dicho Lopo Gomes fiso la dicha manda y la otorgo.

Dixo su muger del dicho Lope Gomes a bozes altas que las oyeron todos los que estauan en la camara y el dicho Lopo Gomes con ellos y lo pudieren oyr de fuera de la camara segund lo desya alto: oyd notario asentad que dise Lopo Gomes que aparta todos sus parientes en çinco soldos y que oyendolo el dicho Lopo Gomes y todos los otros que estaban presentes non lo contradixo el dicho Lope Gomes y que esto es lo que este dicho testigo sabe deste negoçio so cargo del juramento que ha fecho y non sabia fyrmar.

El dicho Antonio Rodrigues, sochantre de Santiago, despues de aver jurado en forma dixo que lo que sabe deste negocio es que este testigo asy como cura, rector y clerigo parrochial de la capilla de Sant Juan que es dentro de la Santa Yglesia de Santiago y del dicho Lope Gomes por que hera su feligres, este año presente al tiempo que el dicho Lopo Gomes fiso su manda y testamento, y que el dicho Antonio Rodrigues, sochantre, dixo al dicho Lopo Gomes: vos señor Lope Gomes otorgays esta manda y testamento que aqui esta escripto por vuestra manda y testamento y ultyma y postrimera voluntad, la qual el dicho testigo tenia en sus manos y que el dicho Lope Gomes respondiera que sy otorgaua, y despues desto que Jacome de Figueras, notario, por ante quien paso la dicha manda torno a preguntar al dicho Lopo Gomes: vos señor Lopo Gomes otorgays esta manda por vuestro testamento, ultyma y postrimera voluntad segund|| aqui esta escripto y quel dicho Lopo Gomes dixera por su boca que aquella otorgaua por su manda y testamento, ultyma y postrimera voluntad y que rebocaua todas y qualesquier mandas, testamentos y cobdeçillos que fasta aquella ora auia fechos, y que queria que aquella valiese y fuese su verdadera manda, testamento, cobdiçillo y ultyma y postrimera voluntad y queria que aquella fisyese fee en juysio y fuera del y fuese fyrme y valedero lo en ella con- 
tenydo y que en este estante Francisco de Treuyño dixera al dicho Lopo Gomes que roguase a este testigo que firmase la dicha su manda pues quel non podia fyrmarla y que luego el dicho Lopo Gomes roguo a este que depone que la fyrmase por quanto el non la podia fyrmar, y que estando el dicho testigo fyrmando la dicha manda quel dicho Lope Gomes dixera que apartaua a todos sus parientes y parientas en çinco soldos.

Preguntado sy el dicho testigo sabia sy los dichos Francisco de Treuyño y Ruy de Pereyra quedaron por herederos y cumplidores del dicho Lope Gomes y dixo que luego yncontinente despues de otorgado el dicho testamento se dixo publico ante todos los testigos en como los dichos Francisco de Treuyño y Ruy de Pereyra quedauan por herederos del dicho Lopo Gomez.

Fue preguntado este dicho testigo sy al tiempo que el dicho Lopo Gomes otorguo la dicha manda sy estaua en su seso, dixo que para el juramento que fecho auia, que a su paresçer deste testigo el dicho Lope Gomes estaua en su seso por las palabras que le oyera desir del dicho testamento y que sy el dicho testigo conosçiera quel dicho Lopo Gomes no estaua en su seso, que el non fyrmara la dicha manda.

Fue preguntado este testigo que pues el hera rector y presbitero parrochial del dicho Lopo Gomes que declarase sy sabia otra cosa alguna y sy sabia quel dicho Lopo Gomes tenia mucha amystad y confiança de los dichos Francisco de Treuyño y Ruy de Pereyra por donde se mouyese a faserlos herederos, y dixo que so cargo del dicho juramento que fecho auia, sabia quel dicho Lopo Gomes tenya muy estrecha amistad y grande con el dicho Francisco Treuyño y asy mismo sabe quel dicho Ruy de Pereyra fue su criado y el le auia dado una notaria desta çibdad, y fiso del onbre y confiaua del lo que tenia, y allende desto, este testigo como sul| cura hablara un dia antes que el dicho Lopo Gomes fallesçiese con Alonso de Canba, vecino desta dicha çibdad, por que hera su muy yntymo amigo del dicho Lopo Gomes para que le consejase que fisyese su testamento y que dexase personas que fuesen de buena conçiençia para que dispusyesen de su fasyenda a serviçio de Dios, lo qual le dixera por el cargo que tenia del ser su parrochiano y feligres, y quel dicho Alonso de Canba le dixera quel dexaua a Francisco Treuyño y que entendia que ya ellos estauan de conçierto anbos a dos que el que primero dellos fallesçiese, el otro quedase en su lugar y destribuyese su fasyenda en serviçio de Dios y que allende desto oyera desir este testigo a la mujer del dicho Lopo Gomez quel dicho Francisco Treuyño non podia faser otra cosa de la dicha fasyenda saluo lo que fizo, que es darla a la Yglesia y Cabildo para faser alguna memoria del dicho defunto porque asy lo avia acordado con el, el dicho Lopo Gomez y que esto hera lo que sabia deste negoçio y fyrmolo de su nombre. Antonio Rodrigues, sochantre.

El dicho Gonzalo de Mellid, testigo presentado por el procurador del dicho cabildo de Santiago, despues de aver jurado en forma devida de derecho, dixo que lo que sabe deste caso es lo syguiente: que este testigo y Ares Peres de Baruta y Martino de Fajeras, çapatero, y Juan de Betanços, Ferrero, y Lopo de Queyçan, xastre, fueron llamados para que fuesen testigos y rogados vinyesen a estar presentes al tiempo que el dicho Lopo Gomes fiso y otorgo la dicha manda, y que vio este testigo como Francisco Treuyño dixo a Lopo Gomes que venya alli el notario para que firmase la manda y quel dicho Lope Gomes respondiera que non podia fyrmar, que mandaua y rogaua y pidia por merçed al sochantre, su capellan, que la fyrmase en su nombre y que dixera el dicho so chantre: vos señor Lopo Gomes otorgays esta manda por vuestra ultyma y postrimera voluntad y quel dicho Lopo Gomes respondio que sy otorgaua y que rebocaua y daua por ningunas todas $\|$ las otras y qualesquier mandas y testamentos que fasta alli auia fecho y otorgado, y que aquella daua por buena y verdadera una ves y dos y 
tres y que aquella ultyma y postrimera voluntad queria que valiese y fuese fyrme, asy como su testamento, cobdiçillo o postrimera voluntad y que apartaua a todos sus parientes en çinco sueldos, lo qual dixera despues que se levantaron y apartaron el dicho capellan y el notario de cabo del, y estonçes la muger suya que estaua mas a çerca del dicho Lopo Gomes dixera al notario que asentase que Lopo Gomes desya que apartaua a todos sus parientes con çinco sueldos y que este testigo aunque estaua algo apartado oyo desir al dicho Lopo Gomes por su boca lo de los dichos çinco sueldos.

Preguntado este testigo sy al tiempo quel dicho Lopo Gomez fiso el dicho testamento sy estaua en su sano seso, dixo que a todo su paresçer deste testigo que tenia muy buen seso y entendimyento como quando sano.

Preguntado sy se leyo la dicha manda y dixo que no se leyo, pero que luego acabado de la otorgar se dixo ante todos los testigos y ante el dicho Antonio Rodrigues, sochantre, como quedauan Francisco de Treuyño y Ruy de Pereyra por herederos del dicho Lopo Gomez, a lo qual nadie no contradixo aunque fue dicho en la camara do estaua el dicho Lopo Gomez y todos los otros, y que esto es lo que este testigo sabe deste caso, socargo de juramento que ha fecho y non sabia fyrmar.

En la dicha çibdad de Santiago, veynte y seys dias del mes de otubre del dicho año, el dicho señor provisor resçibio juramento de Mayor Fernandes, muger que fue de Lopo Gomes de Marçoa y so cargo del dicho juramento prometyo de desir la verdad de lo que supiere y fuere preguntada çerca deste negocio. Testigos que la vieron jurar el arcediano de Neyra y el bachiller Francisco de Vaamonde y Gomes Ballo, el moço y Juan García nabeyro.

Dise que sabe que la noche que fallesçio el dicho Lopo Gomez, su marido, llamaron a çiertas personas que fueron el sochantre de Santiago y a Ares Peres de Baruta y a otras personas para que fuesen testigos y que oyo desir por su boca al dicho Lopo Gomes quel daua por su testamento y manda, la que tenia en sus manos Antonio Rodrigues, sochantre, y Jacome de Figueras, notario, y que aquella hera su testemento y su ultyma y postrimera voluntad\|

Y queria que valiese lo que estaua en ella escripto y que reuocaua todas las otras mandas y cobdeçillos que antes ouiese fecho y aquella daua por su manda, cobdiçillo y testamento y postrimera voluntad, y queria que valiese y que apartaua a sus parientes en çinco sueldos.

Fue preguntada sy sabia la voluntad del dicho Lopo Gomez y que es lo que conosçia della, dixo que sabia muy bien y esta hera la verdad y que la voluntad e yntinçion del dicho Lopo Gomez fue de dexar todos sus bienes y herençia a Dios nuestro señor y a la Santa Yglesia de Santiago, y non a Francisco Treuyño ni a Ruy de Pereyra, y que non enbargante que Francisco Treuyño y el dicho Ruy de Pereyra esten escriptos en el dicho testamento por herederos, que fue con yntinçion y confiança que dellos tuuo que dispornian de su fasyenda y la darian a la dicha Santa Yglesia de Santiago para que se fisyese memoria para syenpre por su anyma.

Preguntado como lo sabia y dixo que por que muchas veses hablando con el dicho Lopo Gomes, su marido, le dixera y declarase voluntad ser aquella y que tanbien le oyo desir que tenia mucha deboçion con la capilla de San Juan que esta dentro de la dicha Santa Yglesia de Santiago do el hera feligres y que conosçio de su voluntad asy mismo de dexar alguna parte de su fasyenda para ella y que, en conclusyon, desia que syenpre conosçio de su voluntad tener deboçion y afiçion a lo que dicho es y que sus bienes non quedasen saluo segund que dicho es y non de otra manera, y que sabe esto que dicho es ser verdad que dexo por herederos a los susodichos con yntençion que destribuyesen los dichos bienes segund dicho es, y non 
de otra manera, porque ella sabe que el dicho Lopo Gomes no tenia yntençion de dexar al dicho Ruy de Pereyra por heredero, saluo sy ella misma non ge lo dixera que confiase del su anyma y que por esta cabsa se mouyo a dexarle por heredero y non para que lleuasen el, ni el otro, los bienes.

Preguntada sy el dicho Lopo Gomes estaua en su seso al tiempo que otorguo el dicho testamento y dixo que para con ella y a su paresçer que el estaua a su seso y que esto es lo que sabe deste el dicho negoçio so cargo del dicho juramento que ha fecho.\|

En primero dia de nouiembre de 1501 años Gil Peres, canónigo, presento por testigo a Martin de Fagares, çapatero, vecino de Santiago, el qual juro en forma de derecho, testigos que le vieron jurar Juan Fernandes, canónigo, y Fernando Vidal y Gomes de Çebolleyro, sus criados.

El dicho Martino de Fageyras despues de aver jurado en forma devida de derecho dixo que lo que deste caso sabe es lo syguiente:

Que este testigo se fallo presente al tiempo quel dicho Lopo Gomes otorguo su manda y que fueron llamados para ello syete o ocho testigos, y que estando asy presentes vio este dicho testigo como el dicho Lopo Gomez dixo por su boca en como el otorgaua por su manda y testamento y postrimera voluntad el testamento que tenia en sus manos el sochantre de Santiago o Jacome de Fegueras, notario, el uno dellos y que rebocaua todas las otras y qualesquier mandas, cobdeçillos y ultymas voluntades que el auia fecho aquella ora, y que las daba por ningunas y de ningund valor y que esta ultyma daua por su testamento y manda, cobdiçillo y ultyma voluntad y que lo dixo una vez y dos y tres que aquella queria que valiese y fuese fyrme y valedera, y que por que el non podia fyrmar rogaua al dicho sochantre que hera su capellan que la fyrmase en su nombre, y que sabia este testigo de la camara donde estaua el dicho Lopo Gomes e otros oyo desyr que apartaua sus parientes en çinco sueldos y que rogaua a Ares Peres que firmase la manda de su nonbre.

Preguntado este testigo sy sabia que el dicho Lopo Gomes dexo por herederos a Francisco Treuyño y a Rodrigo de Pereyra para que ellos lleuasen la fasyenda, o sy los dexo con confiança que dellos touo para que restituyese la fasyenda a la Yglesia para que se le fisyese alguna buena memoria, asy como fe de comysarios.

Dixo que lo que sabia hera que por que Rodrigo de Pereyra hera su criado y le auia dado farta fasyenda y hera onbre que tenia lo que auia menester y asy mismo el dicho Francisco de Treuyño hera onbre rico y mucho su amygo, que este testigo tyene por çierto que se confio dellos para que ellos diesen y entregasen la dicha su fasyenda y herençia a la dicha Yglesia de Santiago, asy como si de comisarios, para que se fesyese alguna memoria por su anyma, segund que lo fisyeron los dichos Francisco de Treuyño y Ruy de Pereira, y que deste caso esto es lo que sabe y que tanbien este testigo oyo desir a muchas personas de cuyos nonbres no se acuerda quel dicho Lopo Gomes tenia en voluntad de hacer sepoltura dentro de la dicha Yglesia y en la capilla de Sant Juan y de faser alargar la dicha capilla y non sabia fyrmar y por eso no fyrmo dos $\|$

Fue preguntado este testigo si al dicho tiempo quel dicho Lopo Gomes otorgo la dicha manda sy estaua en su seso, dixo este testigo que a todo su conosçer y creer y entender, que el conosçio del que estaua en su seso y entendimiento segund que quando hera sano porque ge lo vio desyr con buen reposo y seso y que le vio tomar un caldo y que dixo que hera bueno y que le diese mas y que esto es lo que sabe deste negocio.||

$$
* * *
$$




\section{BiBLIOGRAFÍA}

Barreiro, Xosé Ramón (coord.), Historia da Universidade de Santiago de Compostela. Volumen I. Das orixes ó século XIX, Santiago de Compostela, Universidade de Santiago de Compostela, 1998.

Comesaña Martínez, María Ángela, O tombo do Hospital e Ermida de santa María do Camiño de Pontevedra, Pontevedra, Museo de Pontevedra, 1995.

Costa Rico, Antón, "1526: A fundación da Universidade de Santiago", Cuadernos de Estudios Gallegos, XLVI, 111 (1999), págs. 31- 57.

Cuesta, Luisa, "La Universidad gallega: su pasado, su presente y su porvenir", Boletín de la Universidad de Santiago de Compostela, 7 (1930), págs. 5-38.

Diago Hernando, Máximo "Vecinos de Madrid al servicio de la Real Hacienda durante el reinado de los Reyes Católicos: los arrendadores de rentas", Anales del Instituto de Estudios Madrileños, 47 (2007), págs. 367-416.

Fernández Sánchez, José María y Freire Barreiro, Francisco, Guía de Santiago y sus alrededores, Santiago de Compostela, Imprenta del Seminario Conciliar, 1885 (ed. facsímil Valladolid, Maxtor, 2008).

Gallego Domínguez, Olga, "O primeiro impresor ourensán: Rodrigo de Lavandeira”, Boletín Auriense, XXXVI (2006), págs. 97-124.

García Oro, José, Diego de Muros III y la cultura gallega del siglo XV, Vigo, Galaxia, 1976.

González Seoane, Ernesto (coord.), Álvarez de la Granja, María y Boullón Agrelo, Ana Isabel, Dicionario de dicionarios do galego medieval, Santiago de Compostela, Universidade de Santiago de Compostela, 2006. Edición en línea disponible en http://sli.uvigo.es/DDGM/

Justo Martín, María Xosé, "Lope Gómez de Marzoa na orixe da Universidade, 4 de setembro de 1495", en Gallaecia Fulget (1495-1995). Cinco séculos de historia universitaria, Santiago de Compostela, Universidade de Santiago de Compostela, 1995, págs. 102-107.

López Ferreiro, Antonio, Galicia en el último tercio del siglo XV. Tomo II, A Coruña, Andrés Martínez Editor, 1897.

López Alsina, Fernando, "Marzoa, Melgar, Muros, Fonseca: de la escuela medieval al estudio universitario en Galicia”, Compostellanum, 43 (1998), págs. 797-850.

López Carreira, Anselmo, “Un rexidor de Santiago do século XV”, Brigantium, 6 (1989-1999), págs. 253-270.

López Carreira, Anselmo, A cidade de Ourense no século XV. Sociedade urbana na Galicia baixomedieval, Ourense, Deputación Provincial de Ourense, 1998.

Mollat, Michel, Pobres, humildes y miserables en la Edad Media. Estudio social, México, Fondo de Cultura Económica, 1978.

Neira de Mosquera, Antonio, "La Hermandad de Santiago. 1418", Semanario Pintoresco Español, 44 (1851), pp. 346-348.

Ortego Rico, Pablo, “Arrendadores mayores y arrendadores menores. La configuración de redes socioeconómicas a través de la gestión de la Hacienda Real a fines del siglo XV: algunos ejemplos”, en Ángel Galán Sánchez, Ernesto García Fernández e Imanol Vítores Casado (coords.), En busca de Zaqueo: los recaudadores de impuestos en las épocas medieval y moderna, Madrid, Ministerio de Economía y Hacienda, Instituto de Estudios Fiscales, 2012, págs. 99-116. 
Otero Piñeyro Maseda, Pablo S. y García-Fernández, Miguel, "Los testamentos como fuente para la historia social de la nobleza. Un ejemplo metodológico: tres mandas de los Valladares del siglo XV", Cuadernos de Estudios Gallegos, LX, 126 (2013), págs. 125-169.

Portela Silva, Ermelindo y Pallares Méndez, M. ${ }^{a}$ Carmen, "Muerte y sociedad en la Galicia medieval (siglos XII-XIV)”, Anuario de Estudios Medievales, 15 (1985), págs. 189-202.

Rawcliffe, Carole, Leprosy in medieval England, Woodbridge, Boydell \& Brewer, 2006.

Rubio Martínez, Amparo, "Un hombre de negocios a fines del siglo XV: el notario santiagués Lope Gómez de Marzoa", en David Carvajal de la Vega, Imanol Vítores Casado y Javier Añíbarro Rodríguez (eds.), Poder, fisco y mercado en las ciudades de la Península Ibérica (siglos XIV-XVI), Valladolid, Castilla Ediciones - Colección Historia, 2015, págs. 127-142.

Rodríguez González, Ángel, Libro do Concello de Santiago (1416-1422), con la colaboración de M. a del Pilar Rodríguez Suárez, Santiago de Compostela, Consello da Cultura Galega, 1992.

Sánchez Ameijeiras, Rocío, "Un espectáculo urbano en la Castilla medieval: las honras fúnebres del caballero", Semata, 6 (1994), págs. 141-157.

Sánchez Sánchez, Xosé M., "Don Álvaro Sánchez de Ávila, tenente de Rocha Forte, o la nobleza gallega bajo-medieval en la transición hacia la Modernidad", Cuadernos de Estudios Gallegos, LVII, 123 (2010), págs. 91-193.

Suárez Otero, José, “A Quintana de Paaços. Arquitectura, urbanismo y conflicto social en la Compostela bajomedieval”, Quintana, 1 (2002), págs. 285-300.

Warner, Marina, Tú sola entre las mujeres. El mito y el culto de la Virgen María, Madrid, Taurus, 1991. 